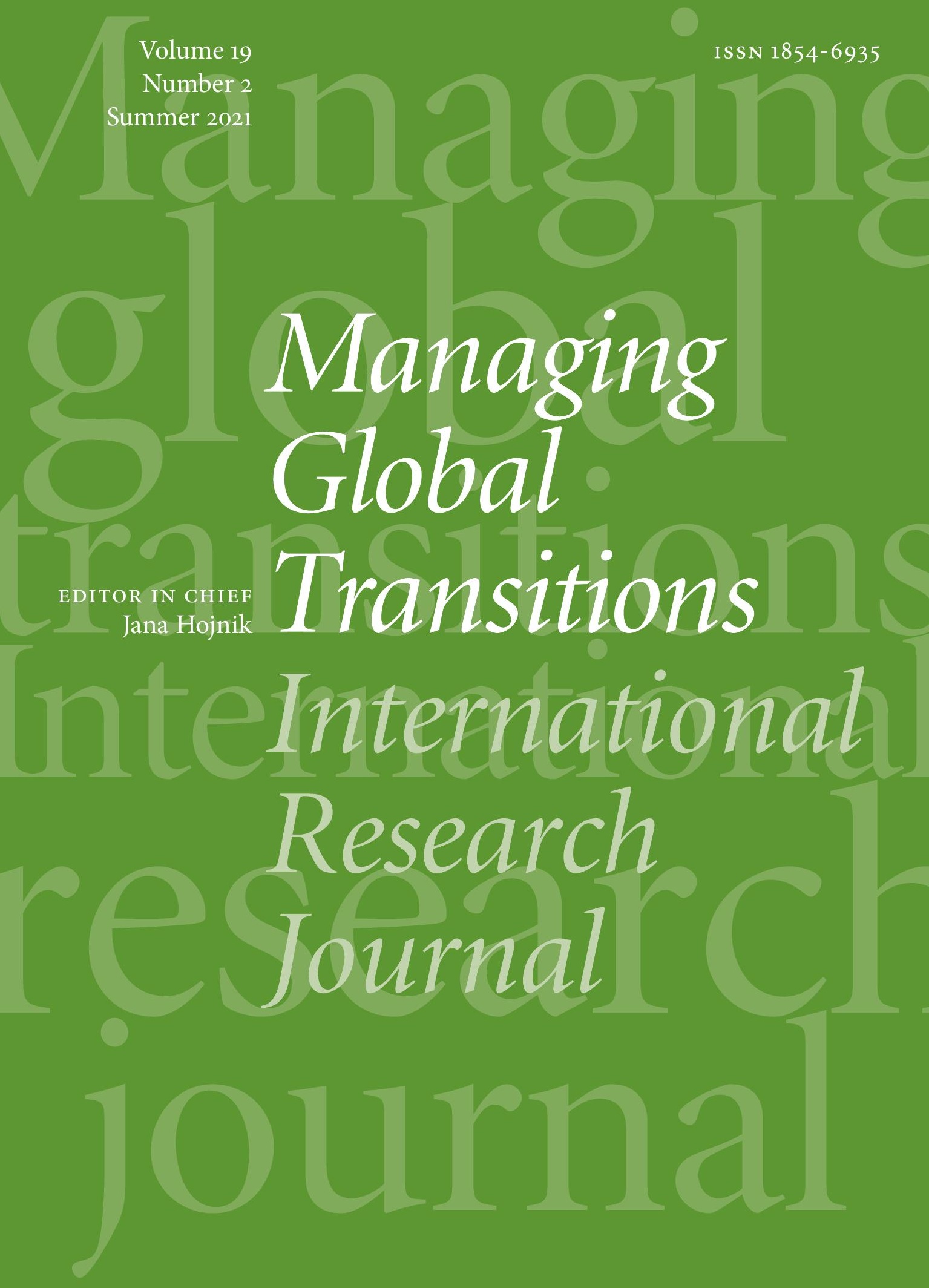




\section{Managing Global Transitions International Research Journal} Is SN 1854-6935 - www.mgt.fm-kp.si

\section{EDITOR IN CHIEF}

Jana Hojnik, University of Primorska, Slovenia, jana.hojnik@fm-kp.si

\section{COEDITOR IN CHIEF}

Egon Žižmond, University of Primorska, Slovenia,egon.zizmond@fm-kp.si

ASSOCIATE EDITORS

Çağrı Bulut, Yaşar University, Turkey, cagri.bulut@yasar.edu.tr

Dean Fantazzini, Moscow State University, Russian Federation, fantazzini@mse-msu.ru

Klemen Kavčič, University of Primorska, Slovenia,klemen.kavcic@fm-kp.si

Suzana Laporšek, University of Primorska, Slovenia,suzana.laporsek@fm-kp.si

Viktor Prokop, University of Pardubice, Czech Republic,viktor.prokop@upce.cz

\section{EDITORIAL BOARD}

Jani Bekő, Univerza v Mariboru, Slovenia, jani.beko@uni-mb.si

Heri Bezić, University of Rijeka, Croatia, bezic@efri.hr

Guido Bortoluzzi, University of Trieste, Italy, guido.bortoluzzi@deams.units.it

David L. Deeds, University of St. Thomas, USA,david.deeds@gmail.com

Evan Douglas, Griffith Universitiy, Australia, e.douglas@griffith.edu.au

Henryk Gurgul, A GH University of Science and Technology, Poland, henryk.gurgul@gmail.com

András Inotai, Hungarian Academy of Sciences, Hungary, inotai.andras@krtk.mta.hu

Felicetta Iovino, University of Sannio, Italy, fiovino@unisannio.it

Hun Joon Park, Yonsei University, South Korea,hjpark@yonsei.ac.kr

Renata Karkowska, University of Warsaw, Poland, rkarkowska@wz.uw.edu.pl

Tanja Kosi Antolič, Institute of Macroeconomic Analysis and Development, Slovenia,tanja.kosi-antolic@gov.si
Leonard H. Lynn, Case Western Reserve University, UsA, leonard.lynn@case.edu Monty Lynn, Abilene Christian University, UsA, monty.lynn@coba.acu.edu

Tatiana S. Manolova, Bentley University, USA,tmanolova@bentley.edu

Massimiliano Marzo, University of Bologna, Italy,massimiliano.marzo@unibo.it

Judita Peterlin, University of Ljubljana, Slovenia, judita.peterlin@ef.uni-lj.si

Mirjana Pejić Bach, University of Zagreb, Croatia,mpejic@efzg.hr

Sanja Peković, University of Crna Gora, Montenegro,psanja@ac.me

Sandra Penger, University of Ljubljana, Slovenia,sandra.penger@ef.uni-lj.si

Zdenko Prohaska, University of Rijeka, Croatia, zdenko.prohaska@efri.hr

José Solana Ibánez, Technical University of Cartagena,Spain, jose.solana@cud.upct.es

Marinko Škare, University of Pula, Croatia, mskare@unipu.hr

Nada Trunk Širca, International School of Social and Business Studies, Slovenia, trunk.nada@gmail.com

Šárka Velčovská, Technical University of Ostrava, Czech Republic, sarka.velcovska@vsb.cz

Manfred Weiss, Johann Wolfgang Goethe University, Germany, m.weiss@jur.uni-frankfurt.de

\section{INDEXING AND ABSTRACTING}

Managing Global Transitions is indexed/ listed in the International Bibliography of the Social Sciences, EconLit, I z z Online, DoAJ, Erih Plus, EconPapers, Cabell's, EBSCO, and ProQuest. 


\section{Managing Global Transitions International Research Joumal}

VOLUME $19 \cdot$ NUMBER 2 - SUMMER 2O21 - ISSN 1854-6935

105 An Ability to Survive Disruptions: Findings from Three Finnish Manufacturing Companies' Supply Challenges during the covid-19 Pandemic Pasi Rönkkö, Aleksi Isopoussu, Jukka Majava, and Osmo Kauppila

127 Corporate Social Responsibility and Its Reporting From a Management Control System Perspective Edward T. Vieira, Jr., Susan Grantham, and Susan D. Sampson

145 Determining the Mediating Effects of Entrepreneurial Self-Efficacy on the Relationship between Organizational Antecedents and Entrepreneurial Orientation Boris Urban and Lehlohonolo Maswabi

167 Analysis of Selected Aspects of an Organisation: The Organisation as an Instrument, an Interest Group and as a Process

Dušan Gošnik and Klemen Kavčič 
AIMS AND SCOPE

Managing Global Transitions (MGT) is a quarterly, scholarly journal that covers diverse aspects of transitions and welcomes research on change and innovation in increasingly digitalized and networked economic environments, from a societal, organizational, and technological perspective. MGT fosters the exchange of ideas, experience, and knowledge among developed and developing countries with different cultural, organizational, and technological traditions. MGT invites original scientific, research, and review papers advancing the field of transitions in societies, organizations, and technologies.

\section{TOPICS COVERED}

\section{Transitions in Societies}

- Geo-political transitions, transition experiments, pathways and mechanisms

- Social, demographic, cross-cultural, ethical, geo-political and security aspects of transitions

- Social change, prosperity, wellbeing, happiness

- Policy making, government regulation, social responsibility

- Knowledge-based society and world futures

- New and emerging metrics for measuring, assessing and evaluating societal transitions

\section{Transitions in Organizations}

- Organizational analysis and design, modeling, developments and changes in organizational learning and behavior

- International strategy and strategic alliances, networked businesses and operations

- Entrepreneurship and leadership, decision making

- Knowledge sourcing and innovation management, personal development, education and training, HRM

- Business systems and business models

- Connective intelligence and collective intelligence in organizational behavior

\section{Transitions in Technologies}

- Managing technological/organizational change and innovation

- Technology networks, technology transfer benefits and risks, technology acquisition and diffusion

- Smart technologies and development discontinuities and sustainability

- Digitalization, гот, Iст, cybernetics, forecasting

- Technological traditions, strategic surprise and response systems

- Studies that promote understanding of the dynamics of socio-technical systems change

- Science and technology policy that fosters transformative advancement

- Modeling technological change in VucA (volatile, uncertain, complex, ambiguous) environments

SUBMISSIONS

The manuscripts should be submitted as e-mail attachment to the editorial office at mgt@fm-kp.si. Detailed guide for authors and publishing ethics statement are available at www.mgt.fm-kp.si.

EDITORIAL OFFICE

University of Primorska

Faculty of Management

Izolska vrata 2, 6000 Koper, Slovenia

mgt@fm-kp.si·www.mgt.fm-kp.si

PUBLISHED BY

University of Primorska Press

Titov trg 4, 6ooo Koper, Slovenia

zalozba@upr.si·www.hippocampus.si

Copy-edited by Susan Cook.

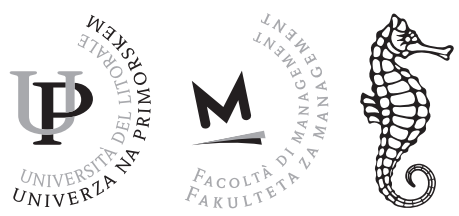

Revija Managing Global Transitions je namenjena mednarodni znanstveni javnosti, izhaja $v$ angleščini. 
An Ability to Survive Disruptions:

Findings from Three Finnish Manufacturing

Companies' Supply Challenges

during the COVID-19 Pandemic

Pasi Rönkkö

University of Oulu, Finland

pasi.ronkko@oulu.fi

Aleksi Isopoussu

University of Oulu, Finland

isopoussu.aleksi@gmail.com

\author{
Jukka Majava \\ University of Oulu, Finland \\ jukka.majava@oulu.fi \\ Osmo Kauppila \\ University of Oulu, Finland \\ Luleå University of Technology, Sweden \\ osmo.kauppila@oulu.fi
}

Being multinational and complex, global supply chains may be extremely vulnerable to sudden crises, such as the recent Covid-19 pandemic. In addition to issues related to the health and lives of people, the pandemic has also had negative impacts on supply chains, and many companies dependent on them have been struggling. The ability to recover from disruptions is called resilience. In this study, the resilience of supply chains is evaluated by studying three globally operating Finnish в 2 в manufacturing companies during the COVID-19 pandemic. The empirical research was conducted by interviewing the companies' supply chain and purchasing operations representatives, analysing the results and comparing the results to the literature. As a result, essential methods to survive during crises and increase the resilience of supply chains were discovered. The results can be utilised in preparing for future crises.

Key Words: resilience, supply chains, disruption, global crises, CoviD-19

JEL Classification: L9, F 23, D 81

(cc) BY.SA https://doi.org/10.26493/1854-6935.19.105-126

\section{Introduction}

In 2020, the world faced a huge disruption in the form of the COVID19 pandemic. COVID-19 affected the lives and health of people, but also had direct and indirect effects on companies because of restrictions, lowering consumption or stalling economies, which directly affected global trade (Kraus et al. 2020; Wilding, Dohrmann, and Wheatley 2020). As a preventive action, many businesses and factories were closed during the pandemic (Rio-Chanona et al. 2020). Negative effects have also been recognised in the global economy, industries and individual businesses, 
politics, the way we live and interact, and supply chains around the globe (Wilding, Dohrmann, and Wheatley 2020). This has caused disruptions in the operations of companies because most industries depend on global supply chains (Kraus et al. 2020).

The global coronavirus pandemic has not been the only crisis in modern history (Giansoldati and Gregori 2018; Kraus et al. 2020; Manuj and Mentzer 2008). For example, before CoviD-19, one of the most-studied severe crises was the Fukushima disaster (Matsuo 2015; Park, Hong, and Roh 2013; Todo, Nakajima, and Matous 2014). Usually, disruptions such as natural disasters or terrorist attacks have brought changes to operations, safety or other issues of companies (Gibb and Buchanan 2006); sudden natural disasters have especially shown the vulnerabilities of supply chains (Manuj and Mentzer 2008).

The risk management of supply chains has been studied (Jüttner, Peck, and Christopher 2003; Manuj and Mentzer 2008; Tang 2006), but in the current study the context is the COVID-19 pandemic-the longest-lasting and most severe crisis this century. Studies on supply chain resilience in the COVID-19 context are emerging (Belhadi et al. 2021; Golan, Jernegan, and Linkov 2020; Ivanov and Dolgui 2020; van Hoek 2020) and studies on the pandemic and its influences on different types of businesses, such as family businesses (Kraus et al. 2020) and small businesses (Bartik et al. 2020) exist, but there is a need for further research in different geographical areas, industries and specific functions, such as supply chain management. Finland has a unique geographical position: a remote location from its main markets (Ministry of Transport and Communications Finland 2005) and a strong trade and export orientation, with international trade accounting for a third of its GDP (International Trade Administration 2020). Thus, the country is strongly dependent on the global economy. In addition, Finnish companies greatly depend on global supply chains.

The present study aims to increase the scientific knowledge on managing the vulnerabilities in supply chains and on surviving disruptions in the global manufacturing industry. We focus on the supply operations of three globally operating Finnish в 2 в manufacturing companies. To support the aims of the current study, the following research questions are posed:

$\mathrm{RQ1}$ What kinds of vulnerabilities and disruptions were identified in the supply chain operations of the studied companies? 
$\mathrm{RQ} 2$ What were the key methods to cope with these vulnerabilities and disruptions?

The present study is qualitative and includes both literature and empirical analyses. The data collection took place during 2020 and thus the COVID-19 pandemic formed the context for the study, but the study focused also on generic vulnerabilities of the case companies' supply chains. The first section includes the study's background, objectives and research questions. The second section presents related literature, that is, supply chain risk management and supply chain resilience (SCRES). The third section describes the research methods, and the fourth section presents the results. The fifth section includes the discussion, with the conclusions being presented in the sixth section.

\section{Literature Review}

Many companies operate globally because of opportunities for high specialisation, wider market area, labour and material costs, tax abatements or having an interest in international product, capital or factor markets (Manuj and Mentzer 2008). Companies may also have unique abilities to manufacture certain products, thus being able to generate international demand (McMillan 1990). To meet this demand, goods are usually produced and delivered through supply chains; sociotechnical networks to identify, target and fulfil a certain demand; a process to decide what, when and how much should be moved where (Davis 1993); or the management of supplies, suppliers, inventory and distribution (Goffin, Szwejczewski, and New 1997). Global supply chains require highly coordinated flows of goods, information, cash and services (Manuj and Mentzer 2008), making them vulnerable to disruptions and highlighting the importance of managing risk and resilience.

\section{RISKS OF SUPPLY CHAINS}

Global supply chains and networks may be extremely vulnerable because of the growing interdependence of companies (Tukamuhabwa et al. 2015), longer paths and shorter clock speeds and overall complexity, all of which can increase the probabilities for disruptions and create smaller error margins (Kleindorfer and Saad 2005). Thus, one disruption may affect and lower the capacity of the entire supply chain (Manuj and Mentzer 2008).

Supply chain risks have been divided into specific categories: lowimpact and high-impact risks (Simchi-Levi, Schmidt, and We 2014), 
TABLE 1 Business-Related Risk Factors

\begin{tabular}{|c|c|}
\hline $\operatorname{Risk}(\mathrm{s})$ & Author(s) \\
\hline $\begin{array}{l}\text { Poor supplier performance, reliability and } \\
\text { logistical risks }\end{array}$ & $\begin{array}{l}\text { Manuj and Mentzer (2008) } \\
\text { Simchi-Levi, Schmidt, and We (2014) }\end{array}$ \\
\hline $\begin{array}{l}\text { Forecast errors and challenges in coordi- } \\
\text { nating supply and demand }\end{array}$ & $\begin{array}{l}\text { Christopher and Lee (2004) } \\
\text { Simchi-Levi, Schmidt, and We (2014) }\end{array}$ \\
\hline Obsolescence & $\begin{array}{l}\text { Christopher and Lee (2004) } \\
\text { Manuj and Mentzer (2008) }\end{array}$ \\
\hline $\begin{array}{l}\text { Inadequate availability of materials and } \\
\text { components, stock-outs, overstocking, } \\
\text { precision of the components and materials } \\
\text { and lack of accuracy }\end{array}$ & Manuj and Mentzer (2008) \\
\hline $\begin{array}{l}\text { Increased dependency of IT networks, } \\
\text { human errors and utility disruptions }\end{array}$ & Cerullo and Cerullo (2004) \\
\hline $\begin{array}{l}\text { Uncertain economic cycles and customer } \\
\text { demands, JiT (just-in-time) }\end{array}$ & Tang (2006) \\
\hline Hidden risk & Simchi-Levi, Schmidt, and We (2014) \\
\hline TABLE 2 High-Impact Risks & \\
\hline $\operatorname{Risk}(\mathrm{s})$ & Author(s) \\
\hline $\begin{array}{l}\text { Natural disasters, political upheavals and } \\
\text { strikes }\end{array}$ & $\begin{array}{l}\text { Cerullo and Cerullo (2004) } \\
\text { Kleindorfer and Saad (2005) } \\
\text { Manuj and Mentzer (2008) } \\
\text { Simchi-Levi, Schmidt, and We (2014) }\end{array}$ \\
\hline Terrorist attacks & $\begin{array}{l}\text { Cerullo and Cerullo (2004) } \\
\text { Kleindorfer and Saad (2005) } \\
\text { Tukamuhabwa et al. (2015) }\end{array}$ \\
\hline Economic disruptions & $\begin{array}{l}\text { Kleindorfer and Saad (2005) } \\
\text { Manuj and Mentzer (2008) }\end{array}$ \\
\hline Competitive and infrastructure risks & Manuj and Mentzer (2008) \\
\hline Factory fires & Simchi-Levi, Schmidt, and We (2014) \\
\hline Changes in enterprises & Gibb and Buchanan (2006) \\
\hline
\end{tabular}

quantitative and qualitative risks (Manuj and Mentzer 2008), external or natural and man-made risks (Tukamuhabwa et al. 2015; Tang 2006) or risks related to disruptions in normal activities (Kleindorfer and Saad 2005). The risks related to businesses are presented in table 1 , whereas the high-impact risks are presented in table 2.

Poor supply and demand coordination (Christopher and Lee 2004; 
TABLE 3 Risk Mitigation Tools

\begin{tabular}{ll}
\hline Risk mitigation tools & Author(s) \\
\hline $\begin{array}{l}\text { Excessive inventories and inventory man- } \\
\text { agement }\end{array}$ & $\begin{array}{l}\text { Christopher and Lee (2004) } \\
\text { Kraljic (1983) } \\
\text { Simchi-Levi, Schmidt, and We (2014) } \\
\text { Tukamuhabwa et al. (2015) }\end{array}$ \\
\hline $\begin{array}{l}\text { Operating with multiple manufacturing } \\
\text { plants and production lines }\end{array}$ & $\begin{array}{l}\text { Kraljic (1983) } \\
\text { Simchi-Levi, Schmidt, and We (2014) }\end{array}$ \\
\hline $\begin{array}{l}\text { Relocating inventories, sourcing and pro- } \\
\text { duction lines }\end{array}$ & $\begin{array}{l}\text { Wilding, Dohrmann, and Wheatley } \\
(2020)\end{array}$ \\
\hline $\begin{array}{l}\text { Supplier selection, building logistics capa- } \\
\text { bilities, risk management culture, supply } \\
\text { chain collaboration, supply network struc- } \\
\text { ture and visibility }\end{array}$ & \\
\hline $\begin{array}{l}\text { System flexibility, strategic partnering } \\
\text { with suppliers, long-term contracts with } \\
\text { penalty clauses and using standardised } \\
\text { components on product structures }\end{array}$ & Simchi-Levi, Schmidt, and We (2014) \\
\hline \begin{tabular}{l} 
Manufacturing multiple products \\
\hline
\end{tabular} & Kraljic (1983) \\
\hline
\end{tabular}

Simchi-Levi, Schmidt, and We 2014) may lead to a bullwhip effect, which may distort the actual product demand. Here, a ripple effect is the impact of disruption propagation through a supply chain (Dolgui, Ivanov, and Sokolov 2018). Hidden risk (Simchi-Levi, Schmidt, and We 2014) means that the total spending on the supplier is relatively low, but the risk's financial impact is high. Changes in operations, such as automation, downsizing, process re-engineering or outsourcing may also introduce new risks (Gibb and Buchanan 2006).

Supply chain risks have traditionally been managed by evaluating the magnitude and likelihood and business impacts of risks and locations, and configuration of technological assets (Simchi-Levi, Schmidt, and We 2014). Wilding, Dohrmann, and Wheatley (2020) state that it is important to know where the suppliers of all tiers are located. The risk potential of traditional events may be evaluated by using historical data, but it is hard to predict high-impact risks that have a low probability of occurring (Simchi-Levi, Schmidt, and We 2014). Supply chain risks can be mitigated by transferring them through insurance and outsourcing, or minimising, reducing, eliminating, absorbing or avoiding them (Gibb and Buchanan 2006). The risk mitigation tools are presented in table 3 . 
Although excessive inventories and inventory management are often mentioned (Christopher and Lee 2004; Kraljic 1983; Simchi-Levi, Schmidt, and We 2014; Tukamuhabwa et al. 2015), Christopher and Lee (2004) add that supply chain risk mitigation methods may lead to financial risks because of obsolete inventory.

\section{RISKS IN SUPPLY OPERATIONS}

Supply operations and supplier management may be a significant competitiveness factor, particularly if a company relies a lot on supplied materials and components (Goffin, Szwejczewski, and New 1997; Kraljic 1983). Good suppliers may also help in new product development, and through achieving better delivery performance through process development (Goffin, Szwejczewski, and New 1997; McMillan 1990), supply security can be improved (Kraljic 1983). Thus, suppliers may have a huge influence on a company's success or failure (Goffin, Szwejczewski, and New 1997).

Regarding supply strategies, single sourcing, the reduction of the supplier base and long-term supplier relationships have been preferred in manufacturing to effectively manage suppliers, increase quality and obtain economic benefits (Goffin, Szwejczewski, and New 1997; McMillan 1990). However, single sourcing is a risk (Wilding, Dohrmann, and Wheatley 2020); here, dual or multisourcing methods are usually preferred to mitigate supplier risks (McMillan 1990; Simchi-Levi, Schmidt, and We 2014). Alternative options also exist, such as single sourcing with back-ups (Goffin, Szwejczewski, and New 1997) to enable the benefits of having few suppliers while reducing risks. Another popular approach is the just-in-time (JIT) method, which requires only a few suppliers that are located close to the buyer's plant, close cooperation and frequent deliveries (Gunasekaran 1999).

The focus of supplier risk mitigation is usually on the suppliers of the strategic components that often depend on a single supplier (Simchi-Levi, Schmidt, and We 2014). The preferred and available sourcing strategies depend on power relations (Kraljic 1983). When buyers are stronger, the strategies may include reducing their own inventories, spot buying and minimising logistics costs. In the case of equality, the operations include optimising and balancing and buffer stocks. If the supplier is stronger, the supply is ensured by contracts.

Business continuity management ( $\mathrm{BCM}$ ) is an enterprise-wide approach to risk identification, mitigation and recovery (Gibb and Buchanan 
2006); it relates closely to supply risks and resilience. As a tool to deliver products despite crises (Gibb and Buchanan 2006), в См includes a risk analysis, selection of mitigation strategies, monitoring and control, implementation, testing, education and training, and review (Cerullo and Cerullo 2004; Gibb and Buchanan 2006; Lam 2002). Cerullo and Cerullo (2004) highlight the importance of testing and training employees to reveal the vulnerabilities of the continuity plan and increase employee performance during disruptions.

\section{SUPPLY CHAIN RESILIENCE}

SCRES refers to a supply chain's ability to recover from a disruption and move either back to the original or a totally new state (Pettit, Croxton, and Fiksel 2019; Ponomarov and Holcomb 2009). Here, resilience is the ability to survive, adapt and grow in the face of crises, and it consists of two factors that need to be balanced: vulnerabilities and capabilities (Pettit, Croxton, and Fiksel 2013). Tukamuhabwa et al. $(2015,5599)$ concisely define SCRES as: 'The adaptive capability of a supply chain to prepare for and/or respond to disruptions, to make a timely and cost-effective recovery, and therefore progress to a post-disruption state of operationsideally, a better state than prior to the disruption.' SCRES may be vital for immediate survival (Cerullo and Cerullo 2004), but it is also critical as a source of a long-term competitive advantage because a proper response to a disruption may improve a company's market position (Tukamuhabwa et al. 2015).

A resilient supply chain should be flexible because the new state may differ from the original state (Ponomarov and Holcomb 2009), and its elements may change in response to a disruption (Tukamuhabwa et al. 2015). When it comes to recovering, supply chains should have the capabilities to anticipate, monitor, respond and learn (Hollnagel 2009), the latter of which will tend to result in increased SCREs (Tukamuhabwa et al. 2015). However, flexibility may also incur costs. Indeed, Jüttner, Peck and Christopher $(2003,203)$ mention: 'Flexibility is often sacrificed for cost reduction.' Jüttner and Maklan (2011) state the possible threats related to SCRES, such as sharing sensitive information and using multisourcing strategies, which may lead to liquidity risk. If excessive amounts of resources are used to mitigate irrelevant risks, the profits of the company may be eroded (Pettit, Croxton, and Fiksel 2013). Additionally, Baghersad and Zobel (2021) find that larger firms are more resilient to supply chain disruptions than smaller firms because they tend to be able to absorb the 
TABLE 4 Identified SCRES Capability Factors

\begin{tabular}{|c|c|}
\hline $\begin{array}{l}\text { SCRES capability } \\
\text { factor }\end{array}$ & Descri \\
\hline $\begin{array}{l}\text { Supply network } \\
\text { structure }\end{array}$ & $\begin{array}{l}\text { The structure is the most suitable for the operations and supply } \\
\text { chain environment. Operations are dispersed to many factories and } \\
\text { production lines (Kraljic 1983; Simchi-Levi, Schmidt, and We 2014; } \\
\text { Wilding, Dohrmann, and Wheatley 2020). }\end{array}$ \\
\hline $\begin{array}{l}\text { Visibility, speed } \\
\text { and flexibility }\end{array}$ & $\begin{array}{l}\text { The visibility enables real-time actions if crises occur. Changes can } \\
\text { be made quickly to enable recovery (Cerullo and Cerullo 2004; } \\
\text { Tukamuhabwa et al. 2015), and structures are flexible to adapt and } \\
\text { enable changes in supply chains (Ponomarov and Holcomb 2009; } \\
\text { Tukamuhabwa et al. 2015). }\end{array}$ \\
\hline $\begin{array}{l}\text { Resilient prac- } \\
\text { tices in supply } \\
\text { operations }\end{array}$ & $\begin{array}{l}\text { Resilience is built, for example, by choosing the right suppliers } \\
\text { and suitable supply methods (Goffin, Szwejczewski, and New } \\
\text { 1997; McMillan 1990), with increased inventory levels and buffers } \\
\text { (Christopher and Lee 2004; Kraljic 1983; Simchi-Levi, Schmidt, and } \\
\text { We 2014). }\end{array}$ \\
\hline Collaboration & $\begin{array}{l}\text { Effective communication and collaboration in the supply chain } \\
\text { with all the stakeholders, mutual objectives and sharing knowledge } \\
\text { related to supplied items and processes (Tukamuhabwa et al. 2015). }\end{array}$ \\
\hline $\begin{array}{l}\text { Culture of re- } \\
\text { silience }\end{array}$ & $\begin{array}{l}\text { Building preparedness by mitigation strategies and plans, recovery } \\
\text { practices, simulations and personnel trainings (Cerullo and Cerullo } \\
\text { 2004; Gibb and Buchanan 2006; Tukamuhabwa et al. 2015). }\end{array}$ \\
\hline
\end{tabular}

risks because of more resources, whereas smaller firms may be more agile and recover faster.

This literature review can be summarised as a set of the key capability factors of SCRES and their definitions. They are presented in table 4 and are used as the basis of the empirical part of the research presented in the next sections.

\section{Research Process}

A case study method was utilised in the current research; it is a useful method when studying contemporary phenomena that cannot be affected by the researcher and looking at these phenomena in a broad context (Yin 2003). Based on the literature review presented in the second section, a semistructured interview guide (Appendix 1) was created to understand the general practices, patterns of material and information flows and the current practices of managing vulnerabilities and disruptions of three case companies. From each of these three globally operating manufacturing companies, key persons related to supply chain operations 
TABLE 5 Case Companies and Interviewees

\begin{tabular}{|c|c|c|c|c|}
\hline Company & Revenue & Personnel & Industry & $\begin{array}{l}\text { Roles of the inter- } \\
\text { viewed }\end{array}$ \\
\hline $\begin{array}{l}\text { Company } 1 \\
\text { (c1) }\end{array}$ & $>2$ billion $€$ & $\begin{array}{l}>10,000 \text { in } \\
\text { more than } 40 \\
\text { countries }\end{array}$ & $\begin{array}{l}\text { Maritime, } \\
\text { Defence and } \\
\text { Aerospace, } \\
\text { and Digital }\end{array}$ & $\begin{array}{l}\text { Development manager, } \\
\text { Operative purchaser, } \\
\text { Sourcing manager, } \\
\text { Strategic purchaser, } \\
\text { and Supply chain man- } \\
\text { ager }\end{array}$ \\
\hline $\begin{array}{l}\text { Company } 2 \\
\text { (C2) }\end{array}$ & $\begin{array}{l}>500 \text { mil- } \\
\text { lion } €\end{array}$ & $\begin{array}{l}>3,000 \text { in sev- } \\
\text { eral countries }\end{array}$ & $\begin{array}{l}\text { Electronics, } \\
\text { contract man- } \\
\text { ufacturer }\end{array}$ & $\begin{array}{l}\text { Value chain director } \\
\text { and Material and logis- } \\
\text { tics manager }\end{array}$ \\
\hline $\begin{array}{l}\text { Company } 3 \\
\text { (c3) }\end{array}$ & $>_{3}$ billion $€$ & $\begin{array}{l}>15,000 \text { in } \\
\text { more than } 50 \\
\text { countries }\end{array}$ & $\begin{array}{l}\text { Fluid engi- } \\
\text { neering and } \\
\text { related tech- } \\
\text { nologies }\end{array}$ & $\begin{array}{l}\text { Category special- } \\
\text { ist, Logistics man- } \\
\text { ager, Operative pur- } \\
\text { chaser/Workflow man- } \\
\text { ager, Purchasing man- } \\
\text { ager, and Operative } \\
\text { purchasing manager }\end{array}$ \\
\hline
\end{tabular}

(table 5) were interviewed. The interviewees had the opportunity to familiarise themselves with the interview guide beforehand. The interviews were transcribed and then analysed to identify key concepts and issues, commonalities and juxtapositions.

\section{Results}

The interview findings were categorised according to the SCRES capability factors presented in table 4 . Abbreviations $\mathrm{C}_{1}, \mathrm{C} 2$ and $\mathrm{C}_{3}$ are used to indicate the companies described in table 5 .

\section{SUPPLY NETWORK STRUCTURE}

All the case companies have global supply networks, and one common supply location is China. Additionally, domestic and Italian suppliers are preferred by $\mathrm{C} 1$, whereas $\mathrm{C}_{3}$ is sourcing globally, mostly from Europe, South Korea, India and the USA. All transportation modes are used (C1, C3), but C2 prefers air freight. The transportation mode used varies depending on location, urgency, price, lead time and the type of component (C1). Air freight availability and the high price were identified as challenges during the pandemic ( 2 2, $\mathrm{C} 3)$. Some air transportations were shifted to rail and road ( $\mathrm{C} 2$ ), but $\mathrm{C} 1$ had disruptions even in train deliveries because of closed borders. 
Multiple-tier supply chains and long lead times were considered vulnerabilities because of decreasing visibility ( $1, \mathrm{C} 3)$. For example, c3's supply chain may consist of up to four tiers of suppliers, making the network very complex. Failures in critical engineered components with long manufacturing times were considered risks ( $\left.\mathrm{C}_{1}, \mathrm{C} 3\right)$. $\mathrm{C} 1$ had recognised the disruptions related to material shortages, machine breakdowns, transportation disruptions and the financial challenges of suppliers.

VISIBILITY, SPEED AND FLEXIBILITY

Visibility was seen as important, and it was evident that a lack of visibility exists in supply chains. Challenges existed in obtaining real-time logistical information (C1, C2, C3), which was seen as a potential risk because of slower reactions to sudden changes ( 1 1, C2). For example, GPs tracking of train deliveries (C1) was used, but in most cases, 'information was only received if the arrival times changed or shipments were stuck' (C1). The problems were usually investigated manually if the goods did not arrive on time (C2). C3 used a manually updated shared folder with the logistics operators and purchasers to track deliveries. However, real-time information was not available.

Deliveries were often confirmed manually, and after that, the companies did not have the visibility or capabilities to track the state of the purchase orders ( $1, \mathrm{C} 2)$; however, $\mathrm{C} 3$ used mostly automatic confirmation, and $\mathrm{C} 2$ had a goal of shifting from manual to automatic order confirmation. Pilot projects were also conducted to increase the visibility in the supply network and improve traceability (c2, c3). C2 saw that 'better visibility would enable more realistic delivery schedules and changes in them.' Another solution for better real-time visibility was the integrated services of logistics providers (C2).

Database interfaces and electronic data interchanges (EDIS) were used between the suppliers and buyers in the cases of $\mathrm{C}_{1}$ and $\mathrm{C}_{3}$ to manage the order log, confirm the orders and provide real-time information related to orders, but with smaller suppliers, the purchase orders and confirmations were done via e-mail and confirmed manually in the Enterprise Resource Planning system (ERP). However, changes in purchasing orders were not possible for $\mathrm{C} 1$, and any changes had to be done via e-mail or phone. In particular, $\mathrm{C} 1$ and $\mathrm{C} 2$ used a lot of manual data transfer by Excel sheets, even though $\mathrm{C} 1$ had recognised information distortions related to this. C1 sent some purchase orders via ERP, but an automatic system to send purchase orders did not exist. Challenges also existed when 
it came to getting the purchase requests at the right time through the ordering process to meet the demand ( $\left.\mathrm{C}_{3}\right)$.

C1 achieved speed by using instructions and checklists to consider the required actions and sharing responsibilities. C1's crisis management team had mandates to appoint a recovery team consisting of key management team members. The importance of flexibility among suppliers was addressed to rearrange production plans and lead times and find new supply options to ensure continuous material flows during disruptions. The inflexibility of logistics partners was recognised as a challenge in deliveries ( $\mathrm{c} 3$ ).

\section{RESILIENT PRACTICES IN SUPPLY OPERATIONS}

To mitigate risks critical components' delivery, stock buffers were built for certain suppliers (C1) and risky regions (C2), but there were also strategic alignments made for reducing inventory levels (c3). Higher inventory costs were covered by a service fee from customers so that faster lead times could be provided ( $\mathrm{C} 2$ ). The risks related to late deliveries were mitigated by having materials delivered in advance before production (c3).

Single suppliers were not usually preferred (C1, C3), except when it came to $\mathrm{C} 2$, which had some reactive backup options, such as spot purchasing and higher payments for suppliers. Other companies, such as C3, were using spot purchasing only on rare occasions. The purchasing volumes of $\mathrm{C} 2$ were low, and a majority of components were purchased from distributors.

Single sourcing vulnerabilities were recognised, especially if the products were tailored, the supplier had intellectual property rights (IPR) related to the products ( $\mathrm{C} 1)$, or the customers demanded using the components of a certain supplier (C2). IPR S prevented other manufacturers from manufacturing certain items, and the demand for using certain suppliers limited the selection of suppliers. The supply practices of the companies with several business units varied; for example, $\mathrm{c} 3$ had no strategic alignments for using certain suppliers or components companywide.

C1 typically used two to three suppliers per component, whereas the number of suppliers of $\mathrm{C} 3$ varied between one and five. C2 and C3 aimed to reduce the suppliers of some components. If many suppliers for a certain component existed and the needs for those components varied, purchases were usually split ( $\left.\mathrm{c}_{3}\right)$. If customer demand suddenly increased, finding sufficient capacity was usually challenging.

Besides multisourcing ( $\left.\mathrm{C}_{1}, \mathrm{C} 3\right)$, the companies prepared for disrup- 
tions by having a wide supplier base (c3), geographical dispersion between suppliers, active communication and building better relationships with the suppliers ( $\left.\mathrm{C}_{2}, \mathrm{C} 3\right)$, audits at the suppliers to discover and solve challenges together $(\mathrm{c} 3)$, purchase contracts, and a continuous evaluation of current and new suppliers ( $1,1, \mathrm{C} 3)$. If there were disruptions in the supply, alternative options were immediately looked for (c3). For example, $\mathrm{C} 2$ used local contact persons in foreign countries to visit the sites and look for optional supply sources. The evaluation of suppliers was seen as important because of quality challenges and safety issues. 'Poor quality components can sometimes lead to temporary sales bans or significant penalty fees' ( 3 3). In addition, $\mathrm{C} 1$ had experienced late deliveries related to subsupplier disruptions. Overall, product complexities vulnerable to many defects were detected (c3).

Long-term partnerships were preferred by $\mathrm{c} 1$. Specific terms were used in the contracts to force suppliers to deliver confirmed orders in all circumstances ( 2 2, C3), and 'better service was ensured by frame agreements with higher costs' (C2). Component refilling methods, such as Kanban, were used in C1 and C2 to automatically fill some needs.

\section{COLLABORATION}

Cooperation with customers was carried out to ensure sufficient capacity of subsuppliers (C1, C2 and C3), but C3 highlighted that clear and transparent communication with customers, especially in a moment of uncertainty, was challenging. $\mathrm{C} 2$ had also faced challenges in communication related to the inaccurate forecasts provided by customers, which led to relatively high inventory levels. Performance levels and risk mitigation procedures were actively presented to customers to create trust and visibility, but customers also inquired about the supplier risks and supply continuity (C2).

Supplier cooperation was exercised to solve supply challenges (C1). It was common for larger suppliers to inform the companies immediately about the changes, whereas smaller suppliers communicated changes later (c3). Joint weekly reviews of the supply issues were performed to enable efficient information sharing, and urgency and severity measurements were executed and communicated within the organisations globally ( $\left.\mathrm{c}_{3}\right)$. Active communication, supplier evaluations and audits were generally recognised as important activities (C1, C2 and C3), especially with problematic and risky suppliers. $\mathrm{C} 1$ considered quality and delivery reviews as important. $\mathrm{C}_{3}$ had outsourced some manufacturing processes, and some challenges related to communication were identified. 


\section{CULTURE OF RESILIENCE}

Risk reviews and mitigation plans were used to assess the risks in supply chains and prepare for them. The reviews included the financial reviews of suppliers, category reviews including single-source risk reviews and quality and delivery reviews. Simulations and regular exercises were conducted to test plans and preparation for unexpected scenarios and to provide useful feedback and improvement ideas, which was considered important for better readiness of the employees (c1). C3 was also randomly ordering excessive amounts of components on purpose to test the capacities of suppliers.

All companies used cross-functional crisis management teams, especially during the CoviD-19 pandemic. Additionally, C3 had a small quality organisation for doing root-cause analysis of disruptive events and past crises and sharing the information to related functions. However, C3 did not have clear roles or defined structures for solving disruptions, whereas $\mathrm{C} 1 \mathrm{had}$ defined ownership of the actions and well-defined roles. C3 preferred frequent discussions between different functions during uncertain times and aimed to develop better disruption management structures.

C2 arranged crisis management team meetings on a weekly basis to inspect material availability of the factories, certain suppliers and affected customers, using an action list; in addition, the management of different factories communicated on a weekly basis the problems and current performance levels. $\mathrm{C} 1$ did not have common risk mitigation procedures with their suppliers, but they had some simple risk management procedures with logistics operators. The creation of recovery plans was considered challenging because disruption types vary and a plan that is too general is not useful (C1). C3 saw that there was a lack of strategic alignments that could enable better management of unexpected changes. C3's different business units operated independently without any clear assessment of vulnerabilities and mitigation plans. $\mathrm{C} 1$ also had plans to demand business continuity plans and risk evaluations from suppliers.

\section{Discussion}

\section{KEY VULNERABILITIES AND DISRUPTIONS}

Research on supply chain resilience in the context of COVID-19 is emerging (Belhadi et al. 2021; Golan, Jernegan, and Linkov 2020), and this study contributes by providing additional and geographic-specific information through real-life findings; a research gap identified by both Ivanov and 
Dolgui (2020) and van Hoek (2020). The most common challenges related to supply chain vulnerabilities were related to a decreased availability of components, IT systems and lack of visibility, delivery challenges and long lead times. Some supplier factories were closed temporarily in risky regions at the beginning of the COVID-19 pandemic. Rio-Chanona et al. (2020) find the same issue, but according to our findings, some suppliers' capacities have decreased even in the long term. Some suppliers may have closed their operations because of low demand, but some may have shifted the production to more profitable goods or goods necessary for national security of supply. The findings also indicate price increases for engineer-to-order (ETO) components, which could be the case of a high-impact disruption, that is, COVID-19, triggering another major risk that affects global competition.

Our findings also show that the case companies suffered from inadequate IT systems, which did not enable real-time information sharing with the suppliers. Thus, supply disturbances were often not reacted to until the deliveries were late. This finding complements the results of Tukamuhabwa et al. (2015), who see the lack of visibility as a key supply chain risk factor. The studied companies had significant challenges in IT connections, which increased the need for manual data transfer. With better visibility and real-time information sharing, the companies could better anticipate and reconfigure the production schedules in time and give more realistic promises to customers, see e.g. Kauppila, Välikangas and Majava (2020).

Kleindorfer and Saad (2005) recognise that there is less room for errors because of longer supply chains and shortened clock speeds. Our results support this claim, especially with multitier supply chains. Besides increased prices, another rare effect was the decreased availability of air transportation. The limited availability and more expensive air freight affected the companies' costs and pricing. In some cases, customers accepted the price change but not in all cases. It was also found that some previously common components, such as electric motors and sensors, suddenly became critical.

It is interesting to note that these vulnerabilities all relate to business risks (table 1 ) that correspond to the risks presented by Manuj and Mentzer (2008), Simchi-Levi, Schmidt, and We (2014) and Cerullo and Cerullo (2004). This could be seen as an indication that the recognition of high-impact risks and building resilience has not yet been realised, despite the impact of COVID-19. 
Common solutions in the studied companies during disruptions included increased warehouse levels and buffer inventories, which have been recognised in several studies (Christopher and Lee 2004; Kraljic 1983; Simchi-Levi, Schmidt, and We 2014; Tukamuhabwa et al. 2015). Another method was to use multisourcing, which has also been discussed by McMillan (1990) and Simchi-Levi, Schmidt, and We (2014). The studied companies preferred to have three to five suppliers for one component, but this was considered challenging and expensive, and there were aims to reduce the number of suppliers. Using multisourcing may be expensive, especially for tailored components, because it leads to smaller batches and special set-up costs (McMillan 1990).

In our study, single sourcing, especially for critical components, was identified as a risk. This is also supported by Wilding, Dohrmann, and Wheatley (2020). Still, both multisourcing and increased warehouse levels may increase costs, and higher inventory levels may lead to obsolescence (Christopher and Lee 2004). On the other hand, a lack of certain components may shut production lines, which is an example of hidden supply risks (Simchi-Levi, Schmidt, and We 2014). Our study also identified a geographical dispersion in sourcing as a method to mitigate regional risks (Wilding, Dohrmann, and Wheatley 2020).

The studied companies also utilised crisis teams consisting of key persons from different functions, which is in line with the literature (Cerullo and Cerullo 2004; Gibb and Buchanan 2006). Frequent internal communication between different functions was used to ensure sufficient material flows between factories during uncertain times. Checklists, clear action plans and the well-defined roles of different employees were used for corrective actions during the disruptions. However, it was also identified that actions should be more proactive for better preparedness. The importance of training of the employees was identified in the results, which is also stressed by Cerullo and Cerullo (2004). In our study, simulations were identified to enable better preparedness to work during stressful situations and test and challenge action plans to find weaknesses, something that could be further emphasised in SCRES research. Building better relationships and close cooperation with different stakeholders in the supply chain, especially using vulnerability assessments that include the most important partners, were identified as important to improve the ability to 
make real-time corrective actions during disruptions, which is similar to the findings of Simchi-Levi, Schmidt, and We (2014). Finally, it was seen as important to understand the capabilities of different suppliers. This relates to supplier management and supply network planning that can be identified as risk mitigation methods, as proposed by, for example, Tukamuhabwa et al. (2015).

\section{Conclusions}

Global supply chains have an inherent vulnerability to disruptions, as the COVID-19 pandemic has shown. In the current article, we studied the vulnerabilities and disruptions in supply chains of three Finnish в 2 в manufacturing companies and what types of methods can be used to address them.

Some common issues were identified in the analysis of the case companies' supply chains. These included decreased capacities of suppliers, increased vulnerability because of multiple supplier tiers or reliance on few suppliers and decreased responsiveness because of a lack of visibility in the supply chain. A noteworthy finding was not only that material flows were disrupted during the COVID-19 pandemic but that some suppliers' capacity seems to have decreased, even in the long term.

The most common methods to address the vulnerabilities and disruptions were increasing inventory levels for critical components, transferring from single- to dual- or multisourcing and decentralisation of the supply chain to mitigate country-specific disruptions. In addition, supplier collaboration was increased to share real-time information and identify common risks.

The results support previous research, yet the COVID-19 pandemic context also revealed unique vulnerabilities and disruptions. In terms of reliability and validity, the current study utilised the case study method, which results in some natural limitations in terms of the generalizability of the findings. Despite careful design, data collection, and analysis by multiple researchers, it must be noted that the study included only three companies in different industries and with different supply chains. Therefore, further studies are recommended to validate and compare the findings in different types of industries and companies. The research did not address systemically how the risks could be reduced in the case of a COVID-19 type of crisis, which could be a topic for further research. Another potential topic for further studies would be the use of more local and circular supply to improve resilience. Could resilience be improved 
by replacing complex multinational supply chains with more effective utilisation of materials and local solutions?

\section{Acknowledgments}

The authors would like to thank the interviewees for their valuable insights. This study is a part of the Reboot IoT Factory project. We also thank Business Finland and other project funders.

\section{References}

Baghersad, M., and C. W. Zobel. 2021. 'Assessing the Extended Impacts of Supply Chain Disruptions on Firms: An Empirical Study.' International Journal of Production Economics 231 (c). https://www.doi.org/10.1016/j .ijpe.2020.107862.

Bartik, A. W., M. Bertrand, Z. Cullen, E. L. Glaeser, M. Luca, and C. Stanton. 2020. 'The Impact of COVID-19 on Small Business Outcomes and Expectations.' PNAS 117 (30): 1765-6.

Belhadi, A., S. Kamble, J. S. C. Charbel, A. Gunasekaran, N. O. Ndubisi, and M. Venkatesh. 2021. 'Manufacturing and Service Supply Chain Resilience to the Covid-19 Outbreak: Lessons Learned from the Automobile and Airline Industries.' Technological Forecasting and Social Change 163:120447.

Cerullo, V., and M. Cerullo. 2004. 'Business Continuity Planning: A Comprehensive Approach.' Information Systems Management 21 (3): 70-8.

Christopher, M., and H. Lee. 2004. 'Mitigating Supply Chain Risk Through Improved Confidence.' International Journal of Physical Distribution \& Logistics Management 34 (5): 388-96.

Davis, T. 1993. 'Effective Supply Chain Management.' Sloan Management Review 34 (4): 35-46.

Dolgui, A., D. Ivanov, and B. Sokolov. 2018. 'Ripple Effect in the Supply Chain: An Analysis and Recent Literature.' International Journal of Production Research 56 (1-2): 414-30.

Giansoldati, M., and T. Gregori. 2018. 'Trade Collapses and Trade Slowdowns: Evidence from Some Central and Eastern European Countries.' Managing Global Transitions 16 (1): 3-18.

Gibb, F., and S. Buchanan. 2006. 'A Framework for Business Continuity Management.' International Journal of Information Management 26 (2): $128-41$.

Goffin, K., M. Szwejczewski, and C. New. 1997. 'When Fewer Can Mean More.' International Journal of Physical Distribution \& Logistics Management 27 (7): 422-36.

Golan, M. S., L. H. Jernegan, and I. Linkov. 2020. 'Trends and Applications of Resilience Analytics in Supply Chain Modeling: Systematic Litera- 
ture Review in the Context of the Covid-19 Pandemic.' Environment Systems and Decisions 40 (2): 222-43.

Gunasekaran, A. 1999. 'Just-in-time Purchasing: An Investigation for Research and Application.' International Journal in Production Economics $59(1-3): 77-84$.

Hollnagel, E. 2009. 'Prologue: The Scope of Resilience Engineering.' In Resilience Engineering in Practice: A Guidebook, edited by E. Hollnagel, J. Pariés, D. D. Woods, and J. Wreathall, xxix-xxxix. Farnhamn: Ashgate.

International Trade Administration. 2020. 'Finland - Country Commercial Guide.' https://www.trade.gov/knowledge-product/finland-marketoverview.

Ivanov, D., and A. Dolgui. 2020. 'Viability of Intertwined Supply Networks: Extending the Supply Chain Resilience Angles towards Survivability' International Journal of Production Research 58 (10): 2904-15.

Jüttner, U., and S. Maklan. 2011. 'Supply Chain Resilience in the Global Financial Crisis: An Empirical Study' Supply Chain Management 16 (4): 246-59.

Jüttner, U., H. Peck, and M. Christopher. 2003. 'Supply Chain Risk Management: Outlining an Agenda for Future Research.' International Journal of Logistics: Research and Applications 6 (4): 197-210.

Kauppila, O., K. Välikangas, and J. Majava. (2020). 'Improving Supply Chain Transparency between a Manufacturer and Suppliers: A Triadic Case Study.' Management and Production Engineering Review 11 (3): 84-91.

Kleindorfer, P. R., and G. H. Saad. 2005. 'Managing Disruption Risks in Supply Chains.' Production and Operations Management 14 (1): 59-68.

Kraljic, P. 1983. 'Purchasing Must Become Supply Management.' Harvard Business Review 61 (5): 109-17.

Kraus S., T. Clauss, M. Breuer, J. Gast, A. Zardini, and V. Tiberius. 2020. 'The Economics of CoviD-19: Initial Empirical Evidence on How Family Firms in Five European Countries Cope with the Corona Crisis.' International Journal of Entrepreneurial Behaviour Research 26 (5): 1067-92.

Lam, W. 2002. 'Ensuring Business Continuity'. IT Professional 4 (3): 19-25. Manuj, I., and J. T. Mentzer. 2008. 'Global Supply Chain Risk Management.' Journal of Business Logistics 29 (1): 133-55.

Matsuo, H. 2015. 'Implications of the Tohoku Earthquake for Toyota's Coordination Mechanism: Supply Chain Disruption of Automotive Semiconductors.' International Journal of Production Economics 161 (c): 217227.

McMillan, J. 1990. 'Managing Suppliers: Incentive Systems in Japanese and U.S. Industry.' Californian Management Review 32 (4): 38-55. 
Ministry of Transport and Communications Finland. 2005. Strengthening Finland's logistics Position: An Action Programme. N. p.: Ministry of Transport and Communications.

Park, Y. W., P. Hong, and J. J. Roh. 2013. 'Supply Chain Lessons from the Catastrophic Natural Disaster in Japan.' Business Horizons 56 (1): 75-85.

Pettit, T. J., K. L. Croxton, and J. Fiksel. 2013. 'Ensuring Supply Chain Resilience: Development and Implementation of an Assessment Tool.' Journal of Business Logistics 34 (1): 46-76.

- 2019. 'The Evolution of Resilience in Supply Chain Management: A Retrospective on Ensuring Supply Chain Resilience.' Journal of Business Logistics 40 (1): 56-65.

Ponomarov, S. Y., and M. C. Holcomb. 2009. 'Understanding the Concept of Supply Chain Resilience.' The International Journal of Logistics Management 20 (1): 124-43.

Rio-Chanona, R. M., P. Mealy, A. Pichler, F. Lafond, and J. D. Farmer. 2020. 'Supply and Demand Shocks in the Covid-19 Pandemic: An Industry and Occupation Perspective.' Covid Economics Vetted and Real-Time Papers, no. 6, 65-103.

Simchi-Levi, D., W. Schmidt, and Y. Wei. 2014. 'From Superstorms to Factory Fires: Managing Unpredictable Supply-Chain Disruptions.' Harvard Business Review 92 (1-2): 96-101.

Tang, C. S. 2006. 'Perspectives in Supply Chain Risk Management.' International Journal of Production Economics 103 (2): 451-88.

Todo, Y., K. Nakajima, and P. Matous. 2014. 'How Do Supply Chain Networks Affect the Resilience of Firms to Natural Disasters? Evidence from the Great East Japan Earthquake.' Journal of Regional Science 55 (2): 209-29.

Tukamuhabwa, B. R., M. Stevenson, J. Busby, and M. Zorzini. 2015. 'Supply Chain Resilience: Definition, Review and Theoretical Foundations for Further Study'. International Journal of Production Research 53 (18): 5592-623.

van Hoek, R. 2020. 'Research Opportunities for a More Resilient PostCoviD-19 Supply Chain: Closing the Gap between Research Findings and Industry Practice.' International Journal of Operations \& Production Management 40 (4): 341-55.

Wilding, R., K. Dohrmann, and M. Wheatley. 2020. 'Post-Coronavirus Supply Chain Recovery: The Journey towards the New Normal.' Deutsche Post DHL Group. https://www.dhl.com/global-en/home/insights-andinnovation/thought-leadership/white-papers/post-coronavirus-supplychain-recovery.html.

Yin, R. K. 2003. Case Study Research: Design and Methods. 3rd ed. Thousand Oaks, cA: Sage. 


\section{Appendix: Interview Guide}

Pre-assignment: please read these questions before the actual interview.

\section{SUPPLY NETWORK}

a Describe briefly what kind of structure you have in your supply chain.

b How does information move between these parts (e.g. how do you receive confirmations or status updates)? For example, by email, phone, website?

c Do you have bottlenecks in your information systems where data needs to be transferred manually?

\section{INBOUND PROCESS}

\subsection{Procurement}

a Describe briefly your sourcing model.

- Which countries do you have sourcing from?

- How many suppliers, on average, do you have per each component?

- Do you have specific contracts (e.g. fixed-period contractual commitment to supply a certain amount of material with certain lead times and regularities)?

- Do you have a backup supplier option? How do you keep low volume suppliers interested?

b Describe briefly your purchasing process (e.g. how do you send a purchasing order to a supplier?).

c How are the purchasing decisions made? What is the level of automation in purchasing decisions?

d What kind of system/practice do you have to keep track of the status of a purchasing order?

e What are the current challenges? What is your most critical component?

\subsection{Inbound Logistics}

a What mode(s) of transportation do you use? What are the lead times? Based on which factors is the mode of transportation chosen?

b Is your company responsible for organising the inbound logistics of the purchased materials?

If yes, what kind of booking procedure/system do you have (e.g. do you have contractual 3 rd party logistics providers, extranet booking system)? Do you plan the routing of logistics by yourself (e.g. preferred countries for customs clearance)?

If not, can you choose the transport mode from the supplier based on e.g. price and lead time?

c How do you track the deliveries?

d What are the current challenges? 


\section{DISRUPTION}

Disruption is a manifestation of a vulnerability, an unanticipated event, that harms the normal operational routines possibly affecting larger entity of a sc. For example, a truck breaking down, a supplier's workforce going on strike, a supplier going out of business or a pandemic affecting inbound material flow.

\subsection{Disruption Mitigation Process}

\subsubsection{Internal Processes}

a Preparation

- What are the methods that you use to anticipate and prepare for potential disruptions?

b Response

- What are the first steps taken after the impact of a disruption?

- What are the key roles or methods you execute during recovery operations?

- Do you inform your partners or other inner organisations of current or projected disruption?

- Are your preparedness plans used during recovery?

- What are the current challenges?

\subsubsection{Suppliers/Customers}

a Are your suppliers/customers helping you to build disruption preparedness? If not, how should they do that?

b Are your suppliers/customers helping to respond to a disruption event? If not, how should they do that?

c Are your suppliers/customers providing you any insights into future events or trends? If not, how should they do that?

3.2 What kind of disruptions are typical in your operations? Can you rate different parts of the supply network in terms of vulnerability to disruptions? Are there any example(s) to share of a disruption event?

\subsubsection{Before Disruption}

a When and how was the disruption first identified?

b How did it actually begin? Did you have any warning?

c Who (in what roles) were the first persons to identify the problem? Who else was affected?

3.2.2 Severity of Impact of the Disruption

a What was the immediate impact of the disruption?

b Did any of your sc partners notice or face any negative impacts caused by the event?

3.2.3 During and After the Disruption

a What was the initial response to the disruption? Was this completely successful? 
b Did any of your actions make the problem even worse?

c Was your primary concern the time length of the impaction or the severity of disruption?

d Can you quantify the negative results caused by the disruption (e.g. financial, lead times)?

e Once the disruption was resolved, were there any takeaways to improve the system for the future?

f Do you have a control room to locate disruptions? If yes, can you provide more information? 


\section{Corporate Social Responsibility \\ and Its Reporting From a Management \\ Control System Perspective}

Edward T. Vieira, Jr.

Simmons University, USA

edward.vieira@simmons.edu

Susan Grantham

University of Hartford, USA

grantham@hartford.edu

Susan D. Sampson

Simmons University, USA

susan.sampson@simmons.edu

Corporate social responsibility (CSR) is a response to stakeholder concerns and signals organisational legitimacy. We propose CSR reporting from a comprehensive and integrated management control system perspective. Reporting parameters start with stated people, planet, and profit goals supported by objectives achieved through legal, ethical/moral, economic, and giving practices. Objectives are measured, assessed, and reported through key performance indicators. These objectives are quantified, sufficiently specific, have a timeline, and identify targeted stakeholder group(s). CSR strategy and its reporting are consistent with organisational mission, values, and strategy. CSR, like most business processes, is a dynamic process occurring over time and adjusting to circumstances sometimes involving trade-offs. CSR reporting ideally reflects this process through providing context and visual depictions of goals, practices, and performance evaluation that demonstrate not only a single period in time, but also trends that may present a more complete picture of an organisation's CSR performance. CSR reporting parameters are proposed.

Key Words: CSR disclosure, CSR reporting, CSR Management Control System, CSR performance evaluation

JEL Classification: M14, M31, M37, M30, M16

(c) Br.sA https://doi.org/10.26493/1854-6935.19.127-144

\section{Introduction}

If a corporate social responsibility (CSR) message is to be effective, it must be viewed as credible. Credibility starts with the message source and then 
extends to the message, eventually developing a bidirectional, transactional relationship of influence between sender and receiver. What makes a message credible starts with it being believable. And, what makes a believable source is related to previous and current actions as well as message content. In the case of this paper, the source is the organisation and the message is its CSR reporting. We broadly use the term organisation as representing corporations, companies, firms, non-profits, and governmental entities.

Credibility stems from perceived trust and competence (Vieira 2019), which are closely related. Both must be present to achieve credibility, and the exercise of competence lays the groundwork for trust. Trust comes when promises are delivered and when shortfalls are disclosed in a spirit of transparency. When communicating with key stakeholders about their concerns, having credibility goes a long way to facilitate and maintain goodwill and legitimacy with them. Credibility is about stakeholders believing that CSR efforts are responsive to their expectations, sincere, and effectively contribute to the betterment of humanity in some way.

Our proposed reporting parameters centre on organisations who have the resources required to develop and implement a comprehensive CSR plan. These types of organisations have management control systems (MCs) in place to operate, manage, and evaluate various aspects of operations, including the execution of CSR plans. An MCs provides a comprehensive and integrated system that offers the opportunity to efficiently and effectively manage ongoing and dynamic processes in proactive and reactive ways relevant to environmental conditions (Winkler 2010). An MCs assures a systematic and effective approach to achieving optimal and sustainable results.

CSR as a major functional contributor to corporate mission faces two major challenges, partly owing to the lack of Mcss and the challenges of integrating the many stakeholder interests into a unified system that is part of, and consistent with, the overall business strategy as are other functional and divisional areas such as finance, sales, manufacturing, supply chain management, operations management, information technology, human resources, international divisions, and so forth. Their internal nature places them at the discretion of management. First, CSR is a response to external as well as internal stakeholders' concerns and expectations, which can come into conflict with internal as well as external parties such as community stakeholders advocating for a companysupported costly social program that may not yield any direct or imme- 
diate benefits to the organisation. Second, there is the nature and level of disclosure. CSR is presented as an annual report available to the general public accessible via a website. Stakeholder reactions to the annual CSR report make management particularly concerned about what is presented and to what degree. Although there has been pressure for CSR disclosure to provide more relevant information (Bonson and Bednarova 2015; Lock 2015), many reports continue to present goals and 'good deed' practices, with little emphasis on the degree to which goals and benchmarked objectives have been achieved within a given timeline.

We propose a comprehensive, practical, and Mcs-based framework for reporting CSR that meets stakeholders' expectations. Utilising this framework to report CSR presupposes the deployment of MCS in CSR and requires an understanding of CSR in the operational context of MCS. We begin with a review of the literature, focusing on what has been done with CSR-MCS in practice and what has not been researched. We then describe our proposed CSR-MCS reporting framework in sufficient detail including the steps required to implement this system.

\section{Review of Related Literature}

Although most publicly traded corporations voluntarily disclose CSR activities, the lack of comprehensiveness, consistency, standards, and quality of reporting has been called into question (Albertini 2019; Bouten et al. 2011; Font et al. 2012; Lock 2015). Many companies fall far short of disclosure requirements recommended by third-party organisations like GRI, ISO, and others (Escrig-Olmedo, Fernandez-Izquierdo, and MunozTorres 2010; Hickman and Cote 2019).

Research suggests that the lack of comprehensiveness and transparency reporting might be owing to management's undue influence on disclosure (Bonson and Bednarova 2015), the perception that stakeholders want or should be given concrete and straightforward content that is easily processed (Arjalies and Mundy 2013; Coombs and Holladay 2009; Crilly, Ni, and Jiang 2016), the focus on financial and accounting metrics, emphasis on prioritised stakeholders (Arvidsson 2010; Costa and Torrecchia 2018; Escrig-Olmedo, Fernandez-Izquierdo, and Munoz-Torres 2010), and pending legal actions (DeTienne and Lewis 2005).

Additionally, because of trade-offs and decisions involving short-term (within the CSR annual reporting cycle) cost for uncertain long-term gain, sustainability is a challenge for some CSR-related efforts (Feder and Weibenberger 2019; Hahn et al. 2010). The benefit is often viewed as ab- 
stract and uncertain, unlike the immediacy of short-term gains, which are concrete, easily presented, and perhaps, in part, why simply reporting practices and good deeds are appealing and often disclosed (Hopwood 2009).

In addition to the dearth of comprehensive CSR disclosure, research in this area has focused on the benefits of CSR reporting, the different levels and nature of practices relevant to stakeholders' varied expectations, differences in management's agenda, the interaction between stakeholders and management, and general descriptions of CSR efforts (Gond et al. 2012; Herremans and Nazari 2016; Laguir, Laguir, and Tchemeni 2019; Schonher, Findler, and Martinuzzi 2017). Moreover, the research on reporting CSR from a MCS perspective is virtually non-existent, with emphasis on general constructs (Rinawiyanti, Huang, and As-Saber 2020).

Yet, research deploying and integrating CSR into control systems, and reporting their efforts and outcomes is important in an ever increasingly complex world (Battaglia et al. 2016). Consequently, this paper proposes a sufficiently detailed and integrated MCs approach for reporting CSR which offers an opportunity for transparency and for contributing to the credibility of the reporting organisation in the eyes of its stakeholders. This framework presupposes the existence of an operating CSR MCs. Without such a system, sufficiently full and transparent CSR disclose cannot take place. Our framework offers reporting details including types of sustainable cSR goals available, types of benchmarked objectives established that serve as the basis for outcome assessment, and categories of CSR practices utilized to attain goals. Reporting these components presents a detailed, comprehensive, and transparent picture of an organisation's good faith CSR efforts.

\section{What is CSR?}

We start with a conceptual definition. Then, we discuss operational CSR parameters, which are the basis for reporting because they serve as concrete evidence of an organisation's effort and performance at meeting stakeholders' expectations.

\section{CONCEPTUALLY, WHAT IS CSR?}

We define CSR as: 'organisational actions that take into account stakeholders' expectations concerning economic, social, and environmental performance' (Aqueveque, Rodrigo, and Duran 2018, 223). This process extends from the short-term to sustainable long-term. These expecta- 
tions require controls necessary to reach, maintain, and adjust them accordingly (Deegan 2002; Hickman and Cote 2019). The process facilitates favourable perceptions from relevant stakeholders. To sustain these efforts and favourable outcomes requires the flexibility to address shifting priorities, the availability of resources, trade-offs such as short-term cost for long-term benefit situations (Johnstone 2018; Munoz-Torres et al. 2009), competing and changing stakeholders' interests, realigning organisational culture, changing leadership, and a host of other internal and external conditions (Hooghiemstra 2000; Jahdi and Acikdilli 2009).

CSR is an organisation's response to address stakeholders' concerns, which involves reporting efforts and performance outcomes. Stakeholders are individuals, groups, and/or organisations who are affected by the organisation's operations and/or who can affect the organisation's operations (Freeman 1984; Parmar et al. 2010).

Stakeholders can be classified as primary or secondary (Metcalfe 1998). Primary stakeholders are those parties without whose continued participation the organisation could not survive. Secondary stakeholders are those parties whose interaction is not required for the organisation to survive. Additionally, research suggests that not all stakeholders are equal (Johnstone 2018) and that some are valued more depending on the industry or sector. In the food, pharmaceutical, and energy industries, Shnayder and Rijnsoever (2018) found such differences. Gubova et al. (2017) discovered differences in prioritising stakeholders among metallurgical/glass building, printing, food business, and machinery industries. Aqueveque, Rodrigo, and Duran (2018) found that stakeholders stemming from an organisation's core business were valued more especially if this involves some essential aspect of regular operations. Findings of a study by Cooper et al. (2001) suggest that those organisations that directly interact with individual consumers tend to focus their CSR attention on customer stakeholders. Sweeney and Coughlan's (2008) CSR reporting research of the financial services, medical pharma, health and beauty pharma, telecommunications, automobile, oil and gas, and retail industries discovered references to corporate responsibilities directed at a variety of stakeholders that varied across sectors.

\section{OPERATIONALLY, WHAT IS CSR?}

How CSR moves from an aspirational idea to reality requires an organised system in place that guides and controls the process and activities, and provides for continuous feedback so that the implementation of CSR 
is adjusted and sustained in accordance with ultimate goals. In other words, the idea of CSR becomes concrete and measurable once it is operationalised.

This system is an MCs. MCss are formal and informal structures, including practices and reporting, put in place by a business to compare the goals and strategy of the organisation against the actual outcomes both nonfinancial and financial on an ongoing basis. This comparison is then reviewed and used to drive managerial decisions across multiple levels of the organisation (Arjalies and Mundy 2013; Cresti 2009).

If CSR reporting is to be transparent and legitimate in the eyes of stakeholders, not only goals and good deeds must be reported, but performance outcomes as well. Outcomes that meet expectations as well as those that fall short must be disclosed. In sum, it is a matter of what the company intends to do, how it will do it, and whether the company did itall critical to comprehensive and transparent CSR (Costa and Torrecchia 2018; Johnstone 2018).

Reporting centred on comprehensive and MCs-based CSR requires not only the operation of such a system, but a clear understanding of it. Therefore, borrowing from MCs principles, the following covers our proposed reporting framework, including the steps required for reporting and an illustration.

- Goals. These are what we hope to attain or achieve and can be general or fairly specific (Vieira 2019). In principle, CSR goals are reached through ethical operating practices that meet socially meaningful standards and stakeholder expectations in a manner consistent and supportive of the organisational mission and business strategy. Sustainable CSR occurs at the intersection of People, Planet, and Profit goals (Carroll 1991; 2016; Elkington 1994).

- People. This type of goal involves adding value to individuals' lives and contributing to society in different ways. Contributions include providing jobs and training; offering safe working conditions; paying taxes used to support society; developing innovations, including technologically-based; and offering attractive healthcare benefits, family leave policies, and desirable pension options.

- Planet. Environmental goals involve the maintenance of natural environmental capital (Goodland 1995) addressing both conservation and pollution mitigation. Some areas of attention are global warming, green engineering and chemistry, air and water quality, alterna- 
tives to depleting natural resources, ecosystems, resource integrity, and addressing pollutants.

- Profit. Economic goals focus on sustainable financial and economic viability such as profit, maintaining cash flow, paying taxes, raising capital, providing cost-effective and competitively priced goods and services, supply chain integrity, and offering attractive owners' equity. Profit goals focus on business strategy and mission, integrating CSR (Massung et al. 2013; Parmar et al. 2010). In sum, CSR captures the way business affects and is affected by the social, economic, and environmental expectations of stakeholders (Coombs and Holladay 2009).

\section{CSR Objectives: The Basis for Performance Evaluation}

Objectives are the means by which we assess CSR goal outcomes (Vieira 2019). They serve two purposes. First, if aligned effectively, they guide the development of implementation practices designed to reach them, which in turn lead to goal achievement. Second, they serve as the basis for measurement and performance evaluation (Ferreira and Otley 2009).

Objectives have four parts. First, an objective must be sufficiently specific. For example, an objective may be to reduce the release of sulphur dioxide into the atmosphere. Second, it must be quantifiable. For instance, an objective may be to reduce by 10 metric tonnes the release of sulphur dioxide into the atmosphere. Alternatively, it might be framed as to reduce the release of sulphur dioxide by $10 \%$ from the previous year. Third, an objective requires a timeline. For example, during 2021, sulphur dioxide release into the atmosphere will be reduced by 10 metric tonnes. Last, if the objective targets specific stakeholders, then the group(s) must be described along with the objective. In other words, identify the key stakeholder group(s) who can impact and/or who are impacted by the CSR objective.

Objectives are categorised variously; we focus on the types appropriate for a CSR MCs, which are interim and summative. Interim measures reflect the ongoing nature of the evaluation process because MCs is dynamic and adjusts to various conditions. Activities and outcomes are monitored, diagnosed and assessed, and deviations are corrected (Simons 2006) on an ongoing basis during the course of CSR operations. It is important for those who develop the annual CSR report to understand this type of monitoring because under- or overperformance in a given period may impact an annual assessment. Thus, interim assessments may serve 
to provide an evidenced-based explication supporting revised planning moving forward. Second, there are summative objectives, which are the final measurement of objectives, used to determine whether an annual goal is achieved. Each goal has at least one corresponding performance objective. Goals or objectives can be weighted as part of a total evaluation system based on organisational and stakeholder priorities.

The specific tools deployed to measure performance outcomes are key performance indicators (KPIS). Typically, a number of KPIS measure an objective. Creating K PIS for an objective requires an understanding about what constitutes a specific objective, how to measure it, and what is required to achieve it.

\section{CSR EVALUATION}

The degree to which benchmarked objectives are met can be rated and reported as outstanding, excellent, very good, good, average, and below standard. The specific numeric reference points are set by the company. They are measured deploying KPIs. Interim measurement of benchmarked objectives using KPIS are used to monitor and assure that CSR is executed as planned and with desired outcomes to date.

The degree to which performance objectives and their KPIS fall within an acceptable range is their tolerance (Collier and Evans 2017). They vary per objective and KPIs. All objectives must rest within their tolerances to be considered successful. As part of the internal assessment, the overall plan requires that a specified percentage of KPIS assigned to the objective have outcomes within tolerances, including all of the prioritized KPIS. This holds true for interim and summative measurements as well. If all or a percentage number of KPI reach their own tolerances, then the objective has been met. If all objectives are met, then the CSR goal has been reached. Although there is no general consensus on a standard method for reporting KPIS (Bouten et el. 2011; Escrig-Olmedo, Fernandez-Izquierdo, and Munoz-Torres 2010), some third-parties provide reporting systems that measure, capture, and evaluate CSR outcomes such as GRI, Iso, Dow Jones, A A 1000, Caux Round Table Principles, Domini 400, eiris, emas, Ethical Trading Initiative, F TSE4 Good Index, and Global Compact (Bonson and Bednarova 2015).

\section{CSR IMPLEMENTATION PRACTICES}

To achieve objectives requires the deployment of CSR implementation practices, which include static or ongoing tasks and activities. The follow- 
ing describes the four types of CSR practices: economical, legal, ethical, and philanthropical.

- Economic. In order to be economically viable and sustainable over the long-term, corporations earn profits through economic activities. Their financial performance can enhance or diminish their capacity to maintain cash-flow, meet shareholder expectations, raise capital for expansion, institute upgrades, conduct research and development, and support other activities or capabilities necessary to be competitive and thrive.

- Legal. Society expects and the law requires businesses to pursue profitable activities lawfully. Think of these legal expectations as codified ethics. Violations of laws, whether civil or criminal, whether intentional or not, damage not only corporate image, but the trust stakeholders place in an organisation.

- Ethical. These practices in business start by discerning what is good or right (contributing to human flourishing), as opposed to that which is bad or wrong (contributing to human impoverishment). Ethics is what guides the conduct of professional activities informed by normative moral values and beliefs consistent with an organisation's mission and values statements (Du, Bhattacharya, and Sen 2010; Vieira 2019). Ethics can fill the gap not addressed by laws.

- Philanthropic. Giving practices include all types of giving such as monetary, scholarships, grants, fundraising, products and services in kind, volunteerism by employees, sponsorship of prosocial cause events, and many more types of discretionary giving. Iв M's On Demand Community Initiative, Microsoft and the Gates Foundation, Gilead Sciences, and Walmart have robust giving programmes. Some philanthropy relates to a corporation's core business while other forms of giving do not (Quelch 2004).

\section{A Proposed CSR Reporting System}

The annual corporate CSR report's audiences are stakeholders and the general public. Details of what is presented can be explored in specialty and more comprehensive reports geared toward different aspects of CSR and specific stakeholders such as third-party reporting agencies, the annual report, environmental disclosures, and SEC filings.

We propose a format that is both sufficiently comprehensive and pragmatic that includes CSR goals, highlighted key practices to reach goals, 
and performance evaluation including summative objectives, tolerances, and ratings. Because of the sustainable nature of CSR, relevant economic data should be presented in the report to demonstrate financial viability over the longer term.

Disclosure of the previous year's CSR efforts would include the following steps:

1. Present the CSR goals.

2. Highlight key practices deployed to achieve the CsR goal.

3. Report the performance objectives required to assess the goal, which might relate to

4. Employ more than one type of assessment such as financial impact. Evaluation may be addressed along with the outcomes as noted in the next one or two steps.

5. Indicate the quantitative outcomes for the targeted timeframe.

6. If informative and adds value, present the corresponding benchmarked tolerances.

7. Cite K PIS if they are exemplars of practices that achieve goals.

8. Provide an assessment term, which may be presented in the narrative such as 'Excellent' or 'Poor' outcome.

9. If appropriate, reference the primary stakeholders for the presented CSR initiative.

These steps provide a systematic guide. Individual situations may vary; however, effectively responding to stakeholder expectations in a credible and transparent manner is critical. For efficacious communication, a clear understanding of the target audience and their expectations is required. Framing the required information in an engaging manner is also part art and part craft.

The example in table 1 illustrates how the components are interrelated and is meant to serve as an internal document designed to capture the information required for CSR disclosure. The reporting format can vary because of organisational circumstances, whether it is presented in a table, infographic, and/or narrative; however, for the most part, the same information would be disclosed. This approach provides a level of comprehension so that the reader understands what the organisation did, how it did it, and whether it met its goal (Lydenberg, Rogers, and Wood 2020).

In this example, the year reported is 2020 . The goal is to convert $25 \%$ of the corporate fleet to fuel efficient vehicles over a five-year period start- 


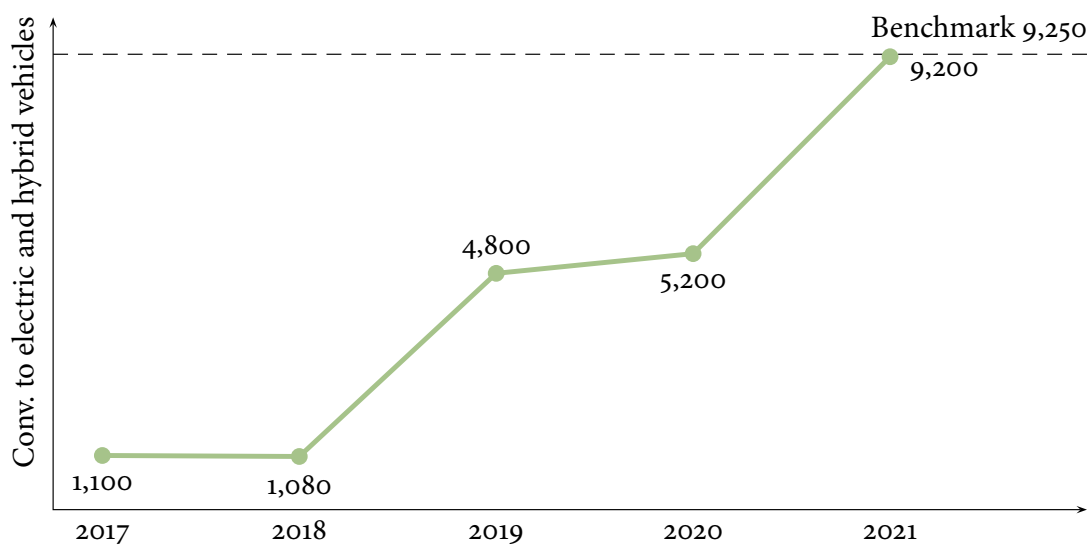

FIGURE 1 Years 2017-2021 Trendline to Convert 25\% of 37,00o Fleet to All-Electric and Hybrid Vehicles

ing 1 January 2020. The bold numbers represent the year-end figures. This will be achieved through two benchmarked performance objectives: converting $3 \%$ of the fleet to electric vehicles and $2 \%$ of the fleet to hybrid vehicles by the end of 2020 with acceptable ranges or tolerances being $2.50-3.00 \%$ and $1.75-2.00 \%$ respectively by the year's end. The actual outcomes were $2.75 \%$ and $2.00 \%$, respectively. These outcomes are rated 'Very Good' and 'Excellent,', respectively.

Although the goal focuses on the replacement of fossil fuel powered vehicles with electric/hybrid vehicles, it is relevant to the environment and thus includes impact data. The financial component speaks to sustainability. As we can see, carbon dioxide emissions were reduced by 2021.13 metric tonnes by the end of the first year. Cost savings were $\$ 935,000$ for the same period. Of course, the ultimate longer-term goal is to reduce air pollution in a cost-efficient manner. Last, a list of primary stakeholders is included.

Although reporting focuses on annual plans and outcomes, much of the effort can be understood more clearly over time relevant to long-term goals, which can be subject to business, market, social, and economic cycles that impact social, environmental and financial ro I (McLymont 2018; Nayak and Patjoshi 2020). For this reason, sometimes trendline depictions convey a clearer longer-term picture of CsR performance. As seen in figure 1, visuals trending positively can be represented through the presentation of graphs and charts. As the adage goes, 'A picture is worth a thousand words' (Speziale and Kloviene 2014). 


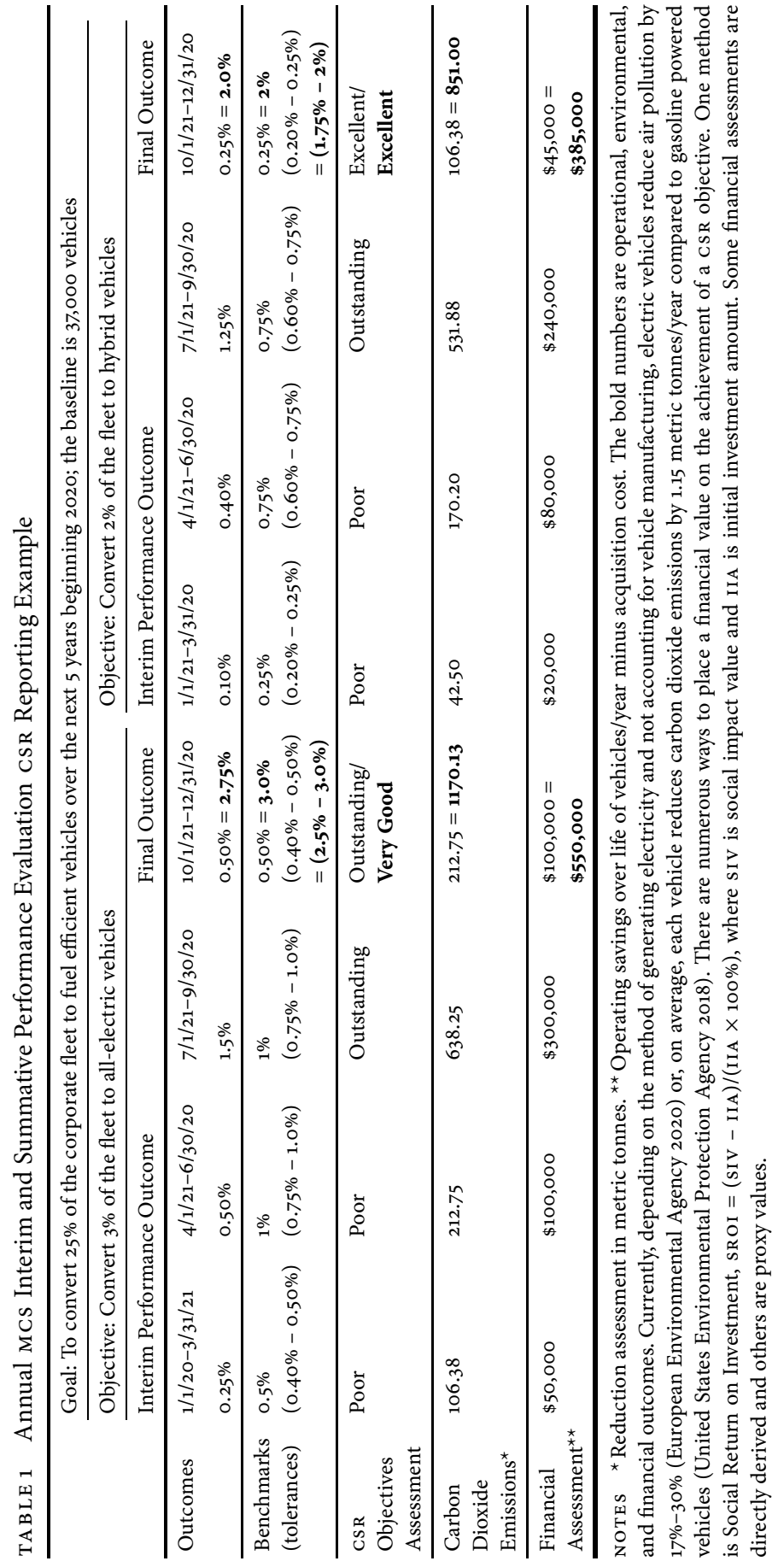


There are a number of other considerations worth mentioning. First, although the above approach provides a common set of general parameters for inclusion in an annual CSR report, each organisation within an industry has a set of unique conditions to various degrees that may require a different component to CSR reporting. Second, outcomes can be measured in financial, and often in other CSR related, metrics. These mixes vary. For instance, financial metrics can be standardised to some measure of ROI, contribution to the bottom line, sales, or some combination of performance measures (McLymont 2018; Nayak and Patjoshi 2020). Nonfinancial measures can be reported as specific reduction of pollutants, educating workforce rates, unit or percentage changes, percentages of a diverse workforce, and so forth. Third, the fourth component of an objective is the identification of the impacted stakeholder group(s). This is essentially an internal consideration and any mention of them in the official annual CSR report would be arbitrary. Last, some organisations have elected to report goals and their assessment in terms of KPIS that are relatable to readers, which would contribute to transparency providing that they are a true representation of outcome evaluation and understandable in terms of the CsR goal.

\section{Conclusion}

Stakeholders, both internal and external, want to know about CSR efforts (Arjalies and Mundy 2013). Unless interested parties are aware of the organisation's response to their concerns, the company's credibility, legitimacy, commitment, and level of stakeholder engagement may be called into question (Arjalies and Mundy 2013; Bacinello, Tontini, and Alberton 2020; Stojanovic et al. 2020). Communicating CSR goals, practices, and outcomes can affect a company's productivity and bottom-line through such influences as the auto-communication effect (Hagen 2008; Spence 2009) where an organisation's messaging about CSR initiatives encourages employees and other internally-related stakeholders such as vendors and suppliers to engage with the organisation, and reinforce a culture of ethical and social responsibility. In sum, effective CSR reporting not only informs, but serves to inspire.

Yet, few large corporations comprehensively deploy MCs for CSR. In reality, planning components are often disjointed and staggered at best (O'Riordan 2010). Scholars acknowledge the importance of a dynamic and integrated approach to CSR that includes business strategy and consistent CSR practices in collaboration with stakeholders in an environ- 
ment that requires adjustment over time owing to trade-offs (Winkler 2010). This can make performance evaluation a moving target (Morsing and Schultz 2006) and may be a significant reason why many organisations with limited resources struggle with the reporting process, resulting largely in the disclosure of aspirational and select good deeds (Hopwood 2009). Understanding this process will aid organisations in their journey toward reporting CSR that is transparent and comprehensive.

\section{References}

Albertini, E. 2019. 'The Contribution of Management Control Systems to Environmental Capabilities.' Journal of Business Ethics 159:1163-80.

Aqueveque, C., P. Rodrigo, and I. J. Duran. 2018. 'Be Bad But (Still) Look Good: Can Controversial Industries Enhance Corporate Reputation through CSR Initiatives.' Business Ethics: A European Review 27:22237.

Arvidsson, S. 2010. 'Communication of Corporate Social Responsibility: A Study of the Views of Management Teams in Large Companies.' Journal of Business Ethics 96:339-54.

Arjalies, D. L., and J. Mundy. 2013. 'The Use of Management Control Systems to Formulate and Implement CSR Strategy: A Levers of Control Perspective.' Management Accounting Research 24 (4): 284-300.

Bacinello, E., G. Tontini, and A. Alberton. 2020. 'Influence of Maturity on Corporate Social Responsibility and Sustainable Innovation in Business Performance.' Corporate Social Responsibility and Environmental Management 27 (2): 749-59.

Battaglia, M., E. Passetti, L. Bianchi, and M. Frey. 2016. 'Managing for Integration: A Longitudinal Analysis of Management Control for Sustainability.' Journal of Cleaner Production 136 (A): 213-25.

Bonson, E., and M. Bednarova. 2015. 'CSR Reporting Practices of Eurozone Companies.' Spanish Accounting Review 18 (2): 182-93.

Bouten, L., P. Everaert, L. Van Liedekerke, L. De Moor, and J. Christiaens. 2011. 'Corporate Social Responsibility Reporting: A Comprehensive Picture.' Accounting Forum 35 (3): 187-204.

Carroll, A. B. 1991. 'The Pyramid of Corporate Social Responsibility: Toward the Moral Management of Organisational Stakeholders.' Business Horizons 34 (4): 39-48.

- 2016. 'Carroll's Pyramid of Corporate Social Responsibility: Taking Another Look.' International Journal of Corporate Social Responsibility $1(3): 1-8$.

Collier, D. A., and J. R. Evans. 2017. oм6 Operations and Supply Chain Management. Boston, MA: Cengage Learning. 
Coombs, T. W., and S. J. Holladay. 2009. 'Corporate Social Responsibility: Missed Opportunity for Institutionalizing Communication Practice.' International Journal of Strategic Communication 3 (2): 93-101.

Cooper, S., D. Crowther, M. Davies, and K. Davis. 2001. Shareholder or Stakeholder Value: The Development of Indicators for the Control and Measurement of Performance. London: The Chartered Institute of Management Accountants.

Costa, M., and P. Torrecchia. 2018. 'The Concept of Value for CSR: A Debate Drawn from Italian Classical Accounting. Corporate Social Responsibility and Environmental Management 25:113-23.

Cresti, E. 2009. 'Sustainability Management Control Systems: Towards a Socially Responsible Planning and Control Framework.' Paper presented at the Oxford Business and Economics Conference, Oxford, 24-6 June.

Crilly, D., N. Ni, and Y. Jiang. 2016. 'Do-No-Harm versus Do-Good Social Responsibility: Attributional Thinking and the Liability of Foreignness.' Strategic Management Journal 37 (7): 1316-29.

Deegan, C. 2002. 'Introduction: The Legitimising Effect of Social and Environmental Disclosures: A Theoretical Foundation.' Accounting, Auditing and Accountability Journal 15 (3): 282-311.

DeTienne, K. B., and L. W. Lewis. 2005. 'The Pragmatic and Ethical Barriers to Corporate Social Responsibility Disclosure: The Nike Case.' Journal of Business Ethics 60:359-76.

Du, S., C. B. Bhattacharya, and S. Sen. 2010. 'Maximizing Business Returns to Corporate Social Responsibility (CSR): The Role of CsR Communication.' International Journal of Management Review 1:8-19.

Elkington, J. 1994. Cannibals with Forks: The Triple Bottom Line of 21st Century Business. Oxford: Capstone.

Escrig-Olmedo, E., M. Fernandez-Izquierdo, and M. Munoz-Torres. 2010. 'Socially Responsible Investing: Sustainability Indices, E S G Rating and Information Provider Agencies.' International Journal of Sustainable Economy 2 (4): 442-61.

European Environmental Agency. 2020. 'EE A Report Confirms: Electric Cars are Better for Climate and Air Quality. https://www.eea.europa .eu/highlights/eea-report-confirms-electric-cars.

Feder, M., and B. E. Weibenberger. 2019. 'Understanding the Behavioural Gap: Why Would Managers (Not) Engage in CsR-Related Activities.' Journal of Management Control 30:95-126.

Ferreira, A., and D. Otley. 2009. 'The Design and Use of Performance Management Systems: An Extended Framework for Analysis.' Management Accounting Research 20:263-82.

Font, X., A. Walmsley, S. Cogotti, L. McCombes, and N. Hausler. 2012. 
'Corporate Social Responsibility: The Disclosure-Performance Gap' Tourism Management 33 (6): 1544-53.

Freeman, R. 1984. Strategic Management: A Stakeholder's Approach. Boston, m A: Pitman.

Gond, J., S. Grubnic, C. Herzig, and J. Moon. 2012. 'Configuring Management Control Systems: Theorizing the Integration of Strategy and Sustainability'. Management Accounting Research 23:205-23.

Goodland, R. 1995. 'The Concept of Environmental Sustainability'. Annual Review of Ecology and Systematics 26:1-24.

Gubova, K., P. Richnak, L. Zendulka, and M. Pavlikova. 2017. 'Importance of Stakeholder Groups in Pursuit of Sustainable Development of Manufacturing Companies.' Journal of Interdisciplinary Research 7 (1): 1548.

Hagen, O. 2008. 'Seduced by their Proactive Image? On Using Auto Communication to Enhance CSR.' Corporate Reputation Review 11 (2): 13044.

Hahn, T., F. Figge, J. Pinkse, and L. Preuss. 2010. 'Trade-Offs in Corporate Sustainability: You Can't Have Your Cake and Eat it.' Business Strategy and the Environment 19 (4): 217-29.

Herremans, I. M., and J. A. Nazari. 2016. 'Sustainability Reporting Driving Forces and Management Control Systems.' Journal of Management Accounting Research 28 (2): 103-24.

Hickman, L. E., and J. Cote. 2019. 'CSR Reporting and Assurance Legitimacy: A Client-Assuror Dyad Investigation.' Journal of Applied Accounting Research 20 (4): 372-93.

Hooghiemstra, R. 200o. 'Corporate Communication and Impression Management: New Perspectives Why Companies Engage in Corporate Social Reporting.' Journal of Business Ethics 27 (1-2): 55-68.

Hopwood, A. G. 2009. 'Accounting and the Environment: Accounting.' Organisations and Society 34 (3-4): 433-9.

Jahdi, K. S., and G. Acikdilli. 2009. 'Marketing Communications and Corporate Social Responsibility (CSR): Marriage of Convenience or Shotgun Wedding.' Journal of Business Ethics 88 (1): 103-13.

Johnstone, L. 2018. 'Environmental Management Decisions in CsR-Based Accounting Research.' Corporate Social Responsibility and Environmental Management 25:1212-22.

Laguir, L., I. Laguir, and E. Tchemeni. 2019. 'Implementing CSR Activities through Management Control Systems: A Formal and Informal Control Perspective.' Accounting, Auditing \& Accountability Journal 32 (2): 531-55.

Lock, I. 2015. 'Analysing Sector-Specific CsR Reporting: Social and Environmental Disclosure to Investors in the Chemicals and Banking and 
Insurance Industry.' Corporate Social Responsibility and Environmental Management 22 (2): 113-28.

Lydenberg, S., J. Rogers, and D. Wood. 2020. From Transparency to Performance: Industry-Based Sustainability Reporting on Key Issues. N. p.: Harvard University.

Massung, E., D. Coyle, K. Carter, M. Jay, and C. Preist. 2013. 'Using Crowdsourcing to Support Pro-Environmental Community Activism.' In CHI'13: Proceedings of the SIGCHI Conference on Human Factors in Computing Systems, 371-80. New York: Association for Computing Machinery.

McLymont, R. 2018. 'CSR Reporting'. Network Journal 25 (3): 20-1.

Metcalfe, C. 1998. 'The Stakeholder Corporation.' Business Ethics: A European Review 7 (1): 30-6.

Morsing, M., and M. Schultz. 2006. 'Corporate Social Responsibility Communication: Stakeholder Information, Response and Involvement Strategies.' Business Ethics: A European Review 15 (4): 323-38.

Munoz-Torres, M. J., M. A. Fernandez-Izquierdo, L. Nieto-Soria, J. M. Rivera-Lirio, E. Escrig-Olmedo, and R. Leon-Soriano. 2009. 'S MES and Corporate Social Responsibility: The Perspective from Spanish Companies.' International Journal of Sustainable Economy 1 (3): 27088.

Nayak, U., and P. K. Patjoshi. 2020. 'Effect of CSR Contribution on Financial Performance: A Study on Automobile Companies of India.' International Journal of Modern Agriculture 9 (3): 981-9.

O’Riordan, L. 2010. 'Perspectives on Corporate Social Responsibility (CSR): Corporate Approaches to Stakeholder Engagement in the Pharmaceutical Industry in the $\mathrm{UK}$ and Germany.' PhD dissertation, Bradford University.

Parmar, B. L., R. E. Freeman, J. S. Harrison, A. C. Wicks, L. Purnell, and S. de Colle. 2010. 'Stakeholder Theory: The State of the Art.' Management Faculty Publications 99:1-62.

Quelch, J. A. 2004. 'ів м on Demand Community.' Case Study 9-504-103. Harvard Business School, Cambridge, MA.

Rinawiyanti, E. D., X. Huang, and S. As-Saber. 2020. 'Adopting Management Control Systems through CS R Strategic Integration and Investigating its Impact on Company Performance: Evidence from Indonesia.' Corporate Governance. https://doi.org/10.1108/CG-04-2020-0150.

Schonher, N., F. Findler, and A. Martinuzzi. 2017. 'Exploring the Interface of CSR and the Sustainable Development Goals.' Transnational Corporations 24 (3): 33-47.

Shnayder, L., and F. J. Rijnsoever. 2018. 'How Expected Outcomes, Stakeholders, and Institutions Influence Corporate Social Responsibility at 
Different Levels of Large Basic Needs Firms.' Business Strategy and the Environment 27:1689-707.

Simons, R. 2006. Levers of Organization Design: How Managers Use Accountability Systems for Greater Performance and Commitment. Boston, M A: Harvard Business School Press.

Spence, C. 2009. 'Social and Environmental Reporting and the Corporate Ego.' Business Strategy and the Environment 18:254-65.

Speziale, M. T., and L. Kloviene. 2014. 'The Relationship between Performance Measurement and Sustainability Reporting: A Literature Review.' Procedia: Social and Behavioral Sciences 156:633-8.

Stojanovic, A., I. Milosevic, S. Arsic, S. Urosevic, and I. Mihaljovic. 2020. 'Corporate Social Responsibility as a Determinant of Employee Loyalty and Business Performance.' Journal of Competitiveness 12 (2): 149-66.

Sweeney, L., and J. Coughlan. 2008. 'Do Different Industries Report Corporate Social Responsibility Differently? An Investigation through the Lens of Stakeholder Theory'. Journal of Marketing Communications 14 (2): 113-24.

United States Environmental Protection Agency. 2018. 'Greenhouse Gas Emissions from a Typical Passenger Vehicle.' https://www.epa.gov/ greenvehicles/greenhouse-gas-emissions-typical-passenger-vehicle.

Vieira, E. T. Jr. 2019. Public Relations Planning. New York: Routledge.

Winkler, H. 2010. 'Sustainability through the Implementation of Sustainable Supply Chain Networks.' International Journal of Sustainable Economy 2 (3): 293-309. 


\title{
Determining the Mediating Effects \\ of Entrepreneurial Self-Efficacy \\ on the Relationship between Organizational Antecedents and Entrepreneurial Orientation
}

\author{
Boris Urban \\ University of Witwatersrand, South Africa \\ boris.urban@wits.ac.za \\ Lehlohonolo Maswabi \\ University of Witwatersrand, South Africa \\ l.maswabi@wits.ac.za
}

A considerable literature points to entrepreneurial orientation (EO) as an essential component in fostering organizational performance. In order to advance theoretical and empirical knowledge in the field of $\mathrm{EO}$, this article undertakes an empirical inquiry into the extent to which entrepreneurial self-efficacy mediates the relationship between organizational antecedents and EO at public hospitals in South Africa. Results support the study hypotheses insofar as organizational structure and performance rewards explain a significant amount of variation in EO, while entrepreneurial selfefficacy partially mediates this relationship. The study makes a novel contribution by highlighting the significance of the connection between different organizational antecedents and $\mathrm{EO}$, while additionally interpreting the mediating effect of entrepreneurial self-efficacy, in an under-researched industry and country context.

Key Words: entrepreneurial orientation, innovativeness, risk taking, proactiveness, organizational antecedents, structure, rewards, entrepreneurial self-efficacy

JEL Classification: D8, J24

(cc)BY-SA https://doi.org/10.26493/1854-6935.19.145-166

\section{Introduction}

Schumpeter (1934) highlighted the role of innovation in the entrepreneurial process, and a Schumpeterian perspective of entrepreneurship, in terms of entrepreneurial organizations, is based upon their new entries (Wales et al. 2020), which offer the likelihood of 'creatively destroying' existing economic establishments. Drawing on a Schumpeterian perspective on innovation and entrepreneurship, entrepreneurial orienta- 
tion (EO) as an organizational strategic orientation is conceived upon firm actions, which manifests as new entries (Estrin, Korosteleva, and Mickiewicz 2020; Kuratko and Morris 2018; Wales et al. 2021). A considerable literature points to corporate entrepreneurship and specifically EO as an important element in organizational development (Covin and Miller 2014; Liu and Wang 2020; Urban 2021). EO embodies an organizational orientation towards new entry and value creation, encapsulating the entrepreneurial decisions, methods, and actions of varying organizational actors in order to generate a competitive advantage (Covin and Lumpkin 2011; Wales et al. 2021).

Notwithstanding the positive empirical findings that EO is a strategic requirement for organizations, several studies show diverse performance consequences (Poon, Ainuddin, and Junit 2006), and subsequently scholars have developed new research questions in order to progress theoretical and empirical knowledge about the field of EO and the entrepreneurial behaviour on which it is established (Covin and Miller 2014; Kuratko and Morris 2018; Liu and Wang 2020; Niemand et al. 2020). In this regard, entrepreneurship in the public sector is highly relevant considering the deficiency of relevant management skills required to foster EO and a potential misinterpretation of what it means and/or is prerequisite to be entrepreneurial in this sector (Demircioglu and Chowdhury 2020; Meynhardt and Diefenbach 2012; Maresova et al. 2020; Morais et al. 2020). Additionally, many researchers note that most EO studies focus on the private sector, where existing theories are inadequate to explain EO in the public sector (Deslatte and Swann 2020; Klein et al. 2010; Morais et al. 2020; Urban and Nkhumishe 2019).

Consequently, in recognising the gap in the literature in terms of understanding the importance of different organizational requirements necessary to foster EO in the public healthcare sector (Klein et al. 2010; Kearney and Meynhardt 2016; Kuratko and Morris 2018; Özcan and Reichstein 2009), particularly from an emerging market perspective where many firms are confronted with uncertain markets, fluctuating market systems and intense global competition (Anwar, Clauss, and Issah 2021), the research question is conveyed as follows: 'To what extent do organizational antecedents, such as structure and rewards, influence Eo through the mediating effects of entrepreneurial self-efficacy in the context of public hospitals in South Africa?'

Recognising that there is a research need for empirical evidence on innovative and EO in the healthcare sector (Carlucci, Mura, and Schiuma 
2019; Deslatte and Swann 2020), this study generates a number of important theoretical and practical contributions to the management literature. By focusing on specific organizational antecedents relevant to the public sphere, the study will extend current theory in terms of understanding the mediating effects of entrepreneurial self-efficacy on the different dimensions of EO. Focusing on organizational structure and performance rewards allows for a more refined analysis, where prior research has found these antecedents to be particularly useful in the public sector context (Kearney and Meynhardt 2016; Maresova et al. 2020). Furthermore, rather than merely testing relationship links between structure, rewards and EO, a more refined approach is implemented to test the mediating effect and interconnectedness of entrepreneurial self-efficacy to the distinctive Eo dimensions of 'innovativeness, risk taking and proactiveness' (Covin and Miller 2014, 12). Moreover, while substitute conceptualisations of organizational antecedents and Eo are to be found, using existing constructs and measures has the benefit of theoretical support (Hornsby et al. 2013; Kloepfer and Castrogiovanni 2018; Kuratko, Morris, and Covin 2011; Liu and Wang 2020). Building on such established constructs allows for replicative studies to take place in the future, and, similar to other recent studies, the study adds to the understanding of mediating variables in the EO relationship with other significant variables (Niemand et al. 2020; Urban 2021).

Additionally, the study context is focused on a single public sector, public hospitals, and takes place in a comparatively under-examined emerging African market context, South Africa, where the health area is one of the key pillars of economic expansion (Gauteng Department of Health 2017). The study took place in the South African public hospital sector in the Gauteng Province, which has the major share of the population in South Africa with approximately 14.7 million people residing in the province (Statistics South Africa 2018). Research shows that public healthcare 'engrosses an enlarged share of income in developed and emerging countries alike, and innovations are needed in this sector to provide care at a reduced cost while augmenting access and furthering quality' (Zuckerman, Dowling, and Richardson 2000). In the healthcare context, healthcare employees' innovativeness plays a crucial role in engendering innovation, but the causes of innovative work behaviour remain largely unobserved (Carlucci, Mura, and Schiuma 2019; Deslatte and Swann 2020; Urban and Maboko 2020). In this regard, prior research results show that complementary effects of different organizational fac- 
tors may positively influence entrepreneurial behaviour (Urban 2021), specifically in terms of organizational levels of Eo (Niemand et al. 2020; Urban and Nkhumishe 2019; Wales et al. 2021). Consequently, the study has important research, policy and practitioner implications as it may assist policy-makers and managers to benefit from a deeper understanding of entrepreneurship as a means to tackle public organizations, and change themselves into adaptable and responsive organizations in order to innovatively deliver improved services to their societies (Morais et al. 2020; Özcan and Reichstein 2009).

The article begins with a synopsis of prior research on E $\mathrm{O}$, self-efficacy and organizational antecedents. The research approach is then delineated in terms of design and which measures are used to collect data. The results are then presented and interpreted. The article ends with conclusions, practical recommendations, study limitations and potential research possibilities.

\section{Entrepreneurial Orientation (E O)}

EO and its constituent dimensions have been extensively employed across studies to describe 'organizations demonstrating entrepreneurial behaviour and processes, where EO is operationalized as the concomitant display of behaviour reflecting innovativeness, risk taking and proactiveness' (Covin and Lumpkin 2011, 861). The relationship between entrepreneurship and innovation is important to clarify, as not only are entrepreneurship and innovation complementary, but a combination of the two is fundamental to organizational success under conditions of a changing and dynamic environment (Kuratko and Morris 2018; Urban 2021; Wales et al. 2021). While entrepreneurship and innovation are positively related to each other and interact to ensure organizational success, scholars note that innovation has to attend to market needs, and compels entrepreneurship if it is to achieve organizational success (Pérez-Luño, Wiklund, and Cabrera 2011; Urban and Maboko 2020).

Similarly, in order for EO to be encouraged within public organizations, more flexible and organic structures are required, as bureaucratic structures characterised by inflexibility and red tape do not align with EO (Kearney, Hisrich, and Roche 2009; Morais et al. 2020). Public sector entrepreneurship has been conceptualised as 'a form of public entrepreneurship that exists within a public or non-profit organisation to remedy legacy problems of bureaucracy, changing organizational structures, processes, and cultures through elements of entrepreneurial orientation, that are inclined to the promotion of good governance, red tape re- 
duction, customer satisfaction, employee empowerment, stakeholder involvement, and cost-efficient performance' (Urban and Nkhumishe 2019, 503). Researchers such as Kearney and Meynhardt (2016) indicate how $\mathrm{EO}$ in the public sphere depends on individual members assuming EO behaviours which need to be fostered by senior management and developed as a key competency where employees feel empowered to behave and act entrepreneurially (Urban 2021). Accordingly for the intention of this study, EO and its constituent dimensions are conceptualised as 'EO in a public sector organisation is demonstrated by the extent to which the top managers are inclined to favour change and innovation for the organization (the innovativeness dimension), to take business related risks (the risk taking dimension), and to take proactive strategic action (the proactiveness dimension), in order to achieve goals and objectives for the greater good of society at large' (Kearney and Meynhardt 2016, 20-1).

\section{Organizational Antecedents}

Organizational antecedents are responsible for creating a supportive environment for EO to thrive within organizations, where the behaviour and entrepreneurial activity of managers and other employees are encouraged (Deslatte and Swann 2020; Morris and Jones 1999). In the private sector context, research on organizational antecedents for encouraging $\mathrm{EO}$ is comparatively recognised insofar as different factors need to be in place, such as relevant 'strategic goals, performance reward schemes, resources, management encouragement, and suitable organizational values which indicate to middle managers and other employees that entrepreneurial behaviour is anticipated' (Hornsby et al. 2013, 23). Research further highlights how organizational antecedents can influence workers' innovativeness both directly and incidentally through the organization's proclivity to innovate and be proactive (Carlucci, Mura, and Schiuma 2019). Other studies highlight that those organizations who innovate by learning and leveraging their internal resources and structure can achieve corporate sustainability, especially since the existing trend of strategic management is principally grounded on paradoxes, incorporating the 'simultaneity of exploratory and exploitative learning' (Wojcik-Karpacz, Karpacz, and Rudawska 2019). Several of these ingrained organizational antecedents from the private sector have been examined in the public sector context with differing results (Maresova et al. 2020; Meynhardt and Diefenbach 2012). For instance, there are contrasting views on the relationship between organizational antecedents and $\mathrm{EO}$, where research highlights that the 'rigid structures of the public sector can inhibit en- 
trepreneurship, and more flexibility and adaptability are required to stimulate EO' (Morris and Jones 1999). Moreover, rewards practices are crucial to performance and therefore organizational circumstances accommodating entrepreneurial behaviour must provide appropriate reward processes and systems (Hornsby et al. 2013; Kearney, Hisrich, and Roche 2009). Consequently, it has been noted that organizational antecedents in the public sector, specifically in terms of organizational structure and performance rewards, warrant further investigations to gain an enhanced appreciation of the complex and multifaceted nature of $\mathrm{EO}$ in this setting (Urban 2021).

\section{ORGANIZATIONAL STRUCTURE AND EO}

Organizational structure is typically viewed as critical for promoting EO (Kuratko and Morris 2018) where structural elements such as hierarchy, red tape, and reporting lines can inhibit or promote entrepreneurial behaviour within the organization. In the context of the public sector organizational structure, Kuratko and Morris (2018) argue that political interference and limited managerial independence impact directly on EO, while others show that 'high power distance' as a component of organizational structure typically inhibits organizational innovation (Strow and Strow 2018; Wojcik-Karpacz, Karpacz, and Rudawska 2019). According to others, the unyielding and highly formalised strategic plans and mechanistic structures of some public entities hamper the managers' ability to stimulate entrepreneurial behaviour amongst employees (Demircioglu and Chowdhury 2020; Kearney, Hisrich, and Roche 2009). However, for EO to take root and flourish within the public sector, greater structural flexibility and adaptability are required for an entrepreneurial culture to permeate the entire organization (Urban and Nkhumishe 2019). In this regard, in recognising that entrepreneurial behaviour can be influenced by the organizational structures, in the first case a hypothesis is formulated which reflects:

$\mathrm{H} 1$ There is a positive relationship between the organizational structure and EO innovativeness, EO risk taking, and EO proactiveness in the context of public hospitals.

\section{PERFORMANCE REWARDS AND EO}

Rewards enhance employee motivation, and organizations with developed performance-based reward systems tend to encourage individuals to pursue challenging work which is important to foster innovation 
(Hornsby et al. 2013). Organizations with well-defined performance rewards create alignment between individual and organizational goals, and encourage EO, since such reward systems tend to generate an awareness of task ownership (Hornsby et al. 2013). Nevertheless, some studies on rewards conducted in the public organizational domain suggest a negative association between rewards and some of the EO dimensions (Urban and Nkhumishe 2019). For instance, not only does a deficiency of performance rewards dissuade innovativeness and risk taking behaviour (Urban and Nkhumishe 2019), but at the same time there is also a general fear of failure as a result of a low risk organizational climate (Kuratko and Morris 2018). Nonetheless, research is evolving which shows that for EO to increase in the public sector organizations, an effectual and meaningful reward system is required, encouraging risk taking and motivation for employees to participate in innovative endeavours (Özcan and Reichstein 2009). Consequently, in line with this emerging stream of findings, it is predicted in the second instance:

$\mathrm{H} 2$ There is a positive relationship between the performance rewards and EO innovativeness, EO risk taking, and EO proactiveness in the context of public hospitals.

\section{Entrepreneurial Self-Efficacy}

Self-efficacy is an imperative motivational concept in entrepreneurship research, where entrepreneurial self-efficacy (ESE) has been used extensively to study entrepreneurial behaviour, as it refers to the 'strengths of a person's belief that he/she is capable of successfully performing the various roles and tasks of an entrepreneur' (Chen, Greene, and Crick 1998, 75). Social cognitive theory ( $\mathrm{SCT}$ ) has much relevance to entrepreneurship in relation to the self-efficacy construct, which is structured on the supposition of a generative capability in which cognitive, social, and behaviour sub skills are organised into combined pathways of action (Bandura 1989; Newman et al. 2019). In this sense, self-efficacy is regarded as an important motivational construct that induces an 'employee's personal goals, choices, emotive reactions, effort, coping and persistence' (Bandura 1989, 14).

Previous research indicates fairly reliable results for self-efficacy as pertaining to entrepreneurial behaviour (Chen and Urban 2018), including its effect on EO (Poon, Ainuddin, and Junit 2006). In the Eo literature, findings highlight the mediating effect of different variables on the connection between organizational antecedents, employees' innovative work 
behaviour and EO (Carlucci, Mura, and Schiuma 2019). While several authors argue that EO has a significant direct influence on performance, others indicate that $\mathrm{EO}$ does not directly affect performance but is reliant on numerous internal factors and competences, which mediate its relationship to performance (Wales et al. 2020). Additionally, studies show how self-efficacy enables an individual to navigate through the rigid organizational structure of many public institutions while remaining selfmotivated to deal with issues of red tape, organizational boundaries, and lack of management support (Kearney and Meynhardt 2016). Moreover, ESE been causally linked to different organizational constructs and often represents a mediation effect on the relationship between intentions, its precursors and outcomes, including aspects of Eo (Anwar, Clauss, and Issah 2021). Studies indicate that as a result of mediating and interaction effects, ESE can positively influence entrepreneurial behaviour, innovation, and possibly lead to higher levels of EO (Chen and Urban 2018).

Consequently, for the intention of this article, ESE is positioned as a mediating variable which can strengthen, diminish, negate, or otherwise alter the association between the organizational antecedents and EO. Recognising that any attempts to introduce or foster EO in public sector organizations are reliant upon the entrepreneurial behaviour of the individual members, in terms of ESE, it is predicted that:

$\mathrm{H} 3 \mathrm{a}$ Entrepreneurial self-efficacy positively mediates the relationship between the organizational structure and EO innovativeness, EO risk taking, and EO proactiveness in the context of public hospitals.

$\mathrm{H} 3 \mathrm{~b}$ Entrepreneurial self-efficacy positively mediates the relationship between performance rewards and EO innovativeness, EO risk taking, and EO proactiveness in the context of public hospitals.

Figure 1 displays the study model which highlights the hypotheses as per the predicted relationships between the various constructs. While the selection of the study constructs, as presented in the literature review, is by no means all-inclusive, it is recognised that there are various organizational factors and processes which regulate how EO is manifested and mediated at the firm level, and that no single set of variables can unequivocally determine the outcome of this process (Chen and Urban 2018).

\section{Research Design}

The study relied on a structured and self-reported survey to collect primary data, with a cross-sectional design. The study hypotheses were sta- 


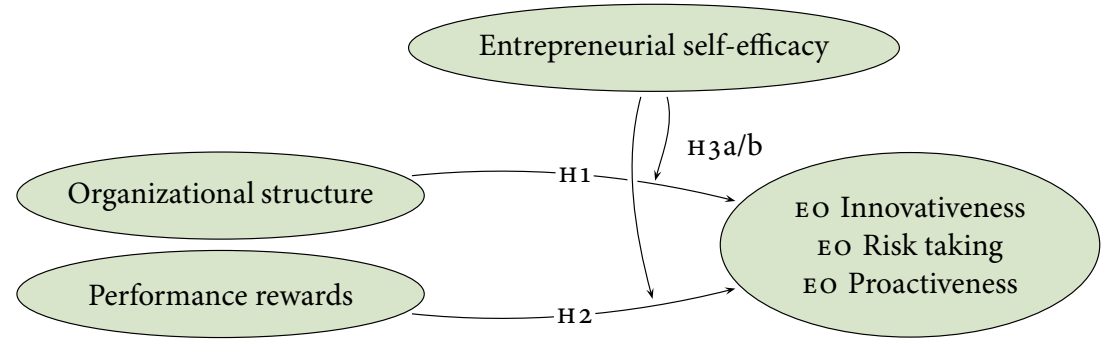

FIGURE 1 Study Model

tistically tested using regression analyses. The population for this study was the thirty-three hospitals located in the Gauteng province in South Africa that are scattered around the province (National Department of Health 2017). According to the Gauteng Department of Health Annual Report (2017), the department has a staff complement of 67,467 staff employed at various levels of different disciplines, of which 111 are senior managers (levels 13-16) and 15,112 are middle managers/supervisors (levels 9-12). The percentage of managers (supervision level/middle level and senior level) is approximately 23 per cent of the total population of employees, which served as the study sampling frame as these study respondents carry the requisite influence to employ resources to capitalise on accessible opportunities and engage in EO activities (Hornsby et al. 2013).

Primary data was collected from the sampled population through an online structured and self-reported survey instrument, over a threemonth period. These online surveys used an anonymous link developed through Qualtrics (study data collection platform), allowing respondents to confidentially complete the questionnaire (Cooper and Schindler 2014). Strict ethical procedures were followed where permissions were sought and obtained from the relevant hospital and/or regional head office, allowing staff to participate voluntarily and anonymously in the survey. Initially, 2500 questionnaires were uniformly disseminated across all hospitals at various levels of care, including central/tertiary, district/provincial hospitals within the Gauteng region. After several data collection attempts, 255 responses were received, yielding a 10.2 per cent response rate. However, due to missing responses the final sample was 172 responses, which were judged adequate for online surveys (Cooper and Schindler 2014). To test for sampling bias, $t$-tests realised no significant differences $(p>0.10)$ between respondents who replied 
earlier versus later in terms of submissions, based on the type of hospital surveyed, which suggests that the sample emerges to be descriptive of the population from which it is extracted.

\section{MEASURING INSTRUMENTS}

Entrepreneurial orientation (EO), as the dependent variable (DV), was operationalised by means of prevailing conceptualisations of $\mathrm{EO}$, in respect of the three dimensions of innovativeness, risk taking and proactiveness (Covin and Lumpkin 2011; Kearney and Meynhardt 2016). EO was evaluated with nine items along a 'seven-point bi-polar Likert scale,' measuring each of the three dimensions. The language in the survey was modified to more accurately reflect the public-sector context. Items such as the following questions were included on each dimension: 'These new services are because of modifications or extensions to existing services,' 'Our hospital is characterised by risk taking of senior management in seizing and exploring risky growth opportunities' and 'Our hospital is characterised by a top management philosophy that emphasises both exploration and experimentation of new service delivery ideas.'

Organizational antecedents, as the independent variables (Ivs) were operationalised on prior constructs as refined by Hornsby et al. (2013), which have been used considerably and are documented as valid and reliable scales (Kuratko and Morris 2018). Organizational structure, measured with 6 items, was concerned with the manner in which an organisation is designed through either an organic or mechanistic structure, and includes questions on decision making structures, nature of specialization, distribution of power and departmentalization. Performance reward was operationalised with five items relating to 'type of systems, their usage and alignment to entrepreneurship.' To safeguard uniformity in scales 'a seven-point Likert scale' comparable to EO was employed.

ESE, as the mediating variable (MV) was operationalised in terms of 'the strength of a person's belief that he/she is capable of successfully performing the various roles and tasks of an entrepreneur' as identified by Chen, Greene, and Crick $(1998,77)$. A seven-point Likert scale was used and the language of the instrument was revised accordingly to ensure that it is aligned to the public hospital context. These included questions such as: 'I have confidence in my ability to manage all challenges imposed by external forces and solve problems in my environment,' and 'I have confidence in my ability to identify and design new services to improve patients/clients service outcomes.' 


\section{DATA ANALYSIS QUALITY CHECKS}

The study followed the Baron and Kenny (1986) method when conducting mediation analysis. Several prescribed steps were undertaken to confirm the results on SPSs and sas to complete the Sobel test for mediation.

Care was taken to minimise any potential risks pertaining to commonmethod-bias. The survey ensured that all questions were in a 'counterbalanced' question order (Cooper and Schindler 2014), and due to anonymity it was anticipated that respondents would answer each question truthfully. Furthermore, statistically to minimise bias, convergent and discriminant validity testing using factor analysis was employed to ensure that distinct factors were being analysed.

To determine if any of the control variables in terms of sample characteristics had any significant interactions with the hypothesised relationships, different 'comparisons of means tests were performed to calculate the consequences of single control variables on the $\mathrm{DV}$ in separation to other control variables' (Cooper and Schindler 2014). However, both $t$ test and individual one-way ANOva tests indicated no significant statistical differences in the $\mathrm{DV}$ in this regard.

Exploratory factor analysis (EFA) was used to evaluate the validity of the study constructs where the Kaiser-Meyer-Olkin Measure (к мо) of Sampling Adequacy showed a value of 0.842 , above the minimum acceptable value of at least 0.5 , and the Bartlett's Test of Sphericity was significant with an approx. Chi-Square 1666.753(136) $(p$-value $=0.000<0.05)$ (Cooper and Schindler 2014). Principal Axis Factoring with the Promax with Kaiser Normalization Rotation Method was used and showed that in some cases, several cross/multiple loadings were present on the extracted factors, especially on items in relation to proactiveness and performance rewards. Consequently, several items were eliminated because they either had communality $(<0.3)$ or had factor loading less than 0.4 and were loading onto more than one factor.

Table 1 shows the final factor pattern matrix, after several iterations and eliminations, where four factors were extracted and explained a total of 69.23 per cent of the variance. Cronbach's Alpha was calculated for each construct to assess the reliability of the scale for the retained items and the results indicate values all above the 0.70 threshold (Cooper and Schindler 2014). Adopting this final factor solution resulted in a change to the study hypotheses where the EO dimension of proactiveness and innovativeness 
TABLE 1 Final Factor Pattern Matrix

\begin{tabular}{|c|c|c|c|c|c|}
\hline \multirow[t]{2}{*}{ Constructs } & & \multicolumn{4}{|c|}{ Factor } \\
\hline & & 1 & 2 & 3 & 4 \\
\hline \multirow[t]{4}{*}{$\begin{array}{l}\text { EO: Risk taking } \\
(\text { EORT) }\end{array}$} & $\begin{array}{l}\text { Q11_EO_RT Our hospital is characterised } \\
\text { by seeking of unusual, novel solutions to } \\
\text { problems by managers }\end{array}$ & 0.965 & & & \\
\hline & $\begin{array}{l}\text { Q10_EO_RT Our hospital is characterised } \\
\text { by risk taking of senior management } \\
\text { in terms of seizing and exploring risky } \\
\text { growth opportunities }\end{array}$ & 0.858 & & & \\
\hline & $\begin{array}{l}\text { Q12_EO_RT Our hospital is characterised } \\
\text { by a top management philosophy that } \\
\text { emphasises both exploration and experi- } \\
\text { mentation of new service delivery ideas }\end{array}$ & 0.740 & & & \\
\hline & $\begin{array}{l}\text { Q13_EO_RT Our hospital encourages } \\
\text { managers to take calculated risks with new } \\
\text { ideas }\end{array}$ & 0.634 & & & \\
\hline \multirow[t]{6}{*}{$\begin{array}{l}\text { Organizational } \\
\text { structure and } \\
\text { rewards (OSR) }\end{array}$} & $\begin{array}{l}\text { Q18_Rewards My manager helps me } \\
\text { get my work done by removing obsta- } \\
\text { cles/challenges }\end{array}$ & & 0.898 & & \\
\hline & $\begin{array}{l}\text { Q21_Rewards My supervisor will give me } \\
\text { special recognition and acknowledgement } \\
\text { if my work performance is good }\end{array}$ & & 0.746 & & \\
\hline & $\begin{array}{l}\text { Q17_Org_Structure Communication in } \\
\text { our reporting structure is both top-down } \\
\text { and down-up }\end{array}$ & & 0.731 & & \\
\hline & $\begin{array}{l}\text { Q15_Org_Structure Our reporting struc- } \\
\text { ture does not hinder the ease and speed } \\
\text { with which we approve new projects and } \\
\text { exploit new opportunities }\end{array}$ & & 0.557 & & \\
\hline & $\begin{array}{l}\text { Q16_Org_Structure The empowering en- } \\
\text { vironment encourages employee creativity } \\
\text { and innovativeness }\end{array}$ & & 0.473 & & \\
\hline & $\begin{array}{l}\text { Q14_Org_Structure Our hospital struc- } \\
\text { ture is flat to facilitate the fluid flow of } \\
\text { communication }\end{array}$ & & 0.464 & & \\
\hline
\end{tabular}

Continued on the next page

were merged into a single construct named innovativeness/proactiveness (EOINPR) and the organizational antecedents were consolidated into a single construct named organizational structure/rewards (OSR). Hence the study hypotheses were changed to reflect the EFA results: 
TAB LE 1 Continued from the previous page

\begin{tabular}{|c|c|c|c|c|}
\hline \multirow[t]{2}{*}{ Constructs } & & \multicolumn{3}{|c|}{ Factor } \\
\hline & & 1 & 2 & 3 \\
\hline \multirow{4}{*}{$\begin{array}{l}\text { EO: Innovative- } \\
\text { ness/proactive- } \\
\text { ness } \\
\text { (EOINPR) }\end{array}$} & $\begin{array}{l}\text { Q4_EO These new services are because } \\
\text { of modifications or extensions to existing } \\
\text { services }\end{array}$ & & \multicolumn{2}{|c|}{0.950} \\
\hline & $\begin{array}{l}\text { Q6_EO Our hospital is characterised by } \\
\text { proactive management that is always pre- } \\
\text { pared for all expected incidences. }\end{array}$ & & \multicolumn{2}{|c|}{0.891} \\
\hline & $\begin{array}{l}\text { Q6_EO Our hospital has introduced new } \\
\text { services in the past two years. }\end{array}$ & & \multicolumn{2}{|c|}{0.882} \\
\hline & $\begin{array}{l}\text { Q7_EO Our hospital has introduced new } \\
\text { creative operational processes compared } \\
\text { with those of other hospitals. }\end{array}$ & & \multicolumn{2}{|c|}{0.491} \\
\hline \multirow[t]{4}{*}{$\begin{array}{l}\text { Entrepreneurial } \\
\text { self-efficacy } \\
\text { (ESE) }\end{array}$} & $\begin{array}{l}\text { Q1_ESE I am confident that I have the } \\
\text { necessary skills and knowledge to grow } \\
\text { beyond my current job status. }\end{array}$ & & \multicolumn{2}{|r|}{0.784} \\
\hline & $\begin{array}{l}\text { Q2_ESE I have confidence in my ability to } \\
\text { manage all challenges and solve problems } \\
\text { caused by external factors }\end{array}$ & & \multicolumn{2}{|r|}{0.642} \\
\hline & $\begin{array}{l}\text { Q3_ESE I have confidence in my ability } \\
\text { to identify and design new services to } \\
\text { improve patients/clients } \mathrm{s} . .\end{array}$ & & \multicolumn{2}{|r|}{0.636} \\
\hline & $\begin{array}{l}\text { Q4_ESE I have confidence in my ability to } \\
\text { supervise, delegate duties and train other } \\
\text { employees }\end{array}$ & & \multicolumn{2}{|r|}{0.619} \\
\hline
\end{tabular}

NOtes Extraction Method: Principal Axis Factoring. Rotation Method: Promax with Kaiser Normalization. Rotation converged in 6 iterations.

$\mathrm{H} 1$ There is a positive relationship between the organizational structure/rewards and EO innovativeness/proactiveness in the context of public hospitals.

$\mathrm{H} 2$ There is a positive relationship between the organizational structure/rewards and Eo risk taking in the context of public hospitals.

$\mathrm{H} 3$ a Entrepreneurial self-efficacy positively mediates the relationship between the organizational structure/performance rewards and EO innovativeness/proactiveness in the context of public hospitals.

$\mathrm{H} 3 \mathrm{~b}$ Entrepreneurial self-efficacy positively mediates the relationship between the organizational structure/performance rewards and EO risk taking in the context of public hospitals. 
TABLE 2 Descriptive Statistics and Correlations

\begin{tabular}{lcccccccr}
\hline & \multicolumn{2}{c}{ Descriptive Statistics } & & \multicolumn{4}{c}{ Pearson's Correlation Coefficients } \\
\cline { 2 - 3 } & $\mathrm{M}$ & $\mathrm{SD}$ & & 1 & 2 & 3 & 4 \\
\hline 1. OSR & 4.35 & 1.43 & & 1 & & & \\
2. ESE & 6.18 & 0.78 & & $0.21^{* * *}$ & 1 & & \\
3. EORT & 4.46 & 1.46 & & $0.67^{* * *}$ & $0.26^{* * *}$ & 1 & \\
4. EOINPR & 5.17 & 1.40 & & $0.39^{* * *}$ & 0.07 & $0.51^{* * *}$ & 1 \\
\hline
\end{tabular}

NOTES M - variable mean, SD - standard deviation, ${ }^{* * *} p<0.01$.

\section{Results and Discussion}

Table 2 displays the mean scores, standard deviations and Pearson correlation coefficients amongst the study variables. Descriptive statistics were calculated, with the highest mean score observed for ESE. There was a strong positive correlation between EOINPR and EORT $(r=0.51$, $p$-value $<0.01)$, and a moderate correlation between OSR that was positive and significantly related to both EORT $(r=0.67, p$-value $<0.01)$ and EOINPR $(r=0.39, p$-value $<0.01)$. There was a very weak and insignificant correlation between ESE and EOINPR $(r=0.07, p$-value $>0.1)$, while the correlation between ESE and EORT was positive and significant ( $r=$ 0.26 , $p$-value $<0.01)$. Furthermore, collinearity diagnostics were computed which reveal 'variable inflation factor ( $\mathrm{V}$ IF) values' of $>1$, which are 'valued as acceptable and can be understood as no evidence of significant incidence of multicollinearity' (Cooper and Schindler 2014).

Multiple linear regression was conducted to test the study hypotheses using forced entry, since the control variables were not included in the study model, and thus there was no order of entry designed for the predictor variables. Fundamentally, two models were formulated, denoted by the following equations: (a) Model $\mathrm{A}=$ EOINPR $=\left(b_{\mathrm{O}}+b_{1}\right.$ OSR $)+\varepsilon_{i}$; (b) Model в $=$ EORT $=\left(b_{\mathrm{O}}+b_{1}\right.$ OSR $)+\varepsilon_{i}$.

Hypothesis $1(\mathrm{H} 1)$ and hypothesis $2\left(\mathrm{H}_{2}\right)$ were tested with a two-step linear regression approach to reflect each of the hypotheses separately, where step 1 (Model A) used only EOINPR as a predictor variable, and EORT was used in step 2 (Model B) to account for any additional variance in OSR. The results with the coefficients are presented in table 3, which shows two columns in terms of Model A ( $\mathrm{H1}$ ) and Model в (н2). The coefficients of determination (R2) was unchanged at 15 per cent for Model A (H1), while a slight change from 45 per cent to 44 per cent was observed with respect to Model в ( $\mathrm{H} 2$ ). In both models the relationships 
TABLE 3 Regression Results for $\mathrm{H} 1$ and $\mathrm{H} 2$

\begin{tabular}{lllllll}
\hline & & \multicolumn{2}{c}{ Model $\mathrm{A}$} & & \multicolumn{2}{c}{ Model в } \\
\cline { 3 - 3 } \cline { 6 - 7 } & & \multicolumn{1}{c}{ в } & $\beta$ & & в & $\beta$ \\
\hline Model 1: EOINPR & Intercept & $5.17^{* * *}$ & 0.00 & & $5.17^{* * *}$ & 0.00 \\
& OSR & $0.38^{* * *}$ & 0.39 & & $0.39^{* * *}$ & 0.39 \\
& $R^{2}$ & 0.15 & & & 0.15 & \\
\hline Model 2: EORT & Intercept & $4.46^{* * *}$ & 0.00 & & $4.46^{* * *}$ & 0.00 \\
& OSR & $0.69^{* * *}$ & 0.67 & & $0.66^{* * *}$ & 0.65 \\
& $R^{2}$ & 0.45 & & & 0.44 & \\
\hline
\end{tabular}

NOTES ${ }^{* * *} p<0.01$.

determined by the regression coefficients were positive and statistically significant, and subsequently $\mathrm{H} 1$ and $\mathrm{H} 2$ are both supported. These findings reaffirm similar findings from prior studies where a positive relationship between organizational structure and EO has been reported (Kearney, Hisrich, and Roche 2009). This positive relationship is important insofar as middle-level managers who function in an organic/flat formation seem to demonstrate higher levels of $\mathrm{E} O$. The rationale for such a relationship may well be prevalent due to structures which encourage less red tape, better collaboration and support, as well as less convoluted communication; all lead towards creating perceptions that entrepreneurial actions are recognised and rewarded (Hornsby et al. 2013).

Hypothesis $3 \mathrm{a}$ (H3a) predicted that entrepreneurial self-efficacy positively mediates the relationship between the organizational structure/performance rewards and $\mathrm{EO}$ innovativeness/proactiveness. Hypothesis $3 \mathrm{~b}$ $(\mathrm{H} 3 \mathrm{~b})$ predicted that entrepreneurial self-efficacy positively mediates the relationship between the organizational structure/performance rewards and EO risk taking. Both of these hypotheses were tested with mediation regression analyses where the mediation parameter comparisons results are displayed in table 4 and 5 , respectively.

Table 4, in terms of $\mathrm{H} 3 \mathrm{a}$, highlights that OSR significantly predicts EOINPR in path $c$ of the model, where $F(8,163)=6.17, p<0.01, R^{2}=0.23$, $\beta=0.422, p<0.01$, and suggests that when OSR increases by 1 unit, EOINPR increases by 0.23 units. OSR + ESE together significantly predict EOINPR in path $c^{\prime}=(a \times b), F(9,162)=5.48, p<0.01, R^{2}=0.23$. Similarly, ESE significantly predicts EOINPR in path $b$, where $F(9,162)=$ 5.48, $p<0.01, R^{2}=0.23, \beta=0.06, p=0.66$, but was not significant. In terms of the Sobel Test, path $a=0.09$, path $b=0.06$, path $c=0.422$ and 
TABLE 4 Mediation Results for H3: ESE Effect on OSR and EOINPR

\begin{tabular}{|c|c|c|c|c|c|c|c|c|c|}
\hline & \multicolumn{3}{|c|}{ OSR > EO_I } & \multicolumn{3}{|c|}{ OSR + ESE > EO_1 } & \multicolumn{3}{|c|}{ OSR $>$ ESE } \\
\hline & B & SE & $\beta$ & B & SE & $\beta$ & B & SE & $\beta$ \\
\hline Intercept & $3 \cdot 50^{\star * *}$ & 0.32 & & $3.58^{\star * *}$ & 0.80 & & $5.69^{* * *}$ & 0.19 & \\
\hline OsR & $0.42^{* * *}$ & 0.07 & 0.42 & $0.42^{\star * *}$ & 0.07 & 0.42 & $0.09^{\star *}$ & 0.04 & 0.09 \\
\hline ESE & & & & 0.06 & 0.13 & 0.06 & & & \\
\hline$F$ & $6.17^{\star * *}$ & & & $5 \cdot 48^{\star * *}$ & & & $2.00^{\star *}$ & & \\
\hline$R^{2}$ & 0.15 & & & 0.15 & & & 0.09 & & \\
\hline
\end{tabular}

NOTES Notes for parameters: $\mathrm{B}=$ unstandardized parameters, $\beta=$ standardized parameters, ${ }^{* *} p<0.01,{ }^{* *} p<0.05,{ }^{\star} p<0.10$.

TABLE 5 Mediation Results for H3: ESE Effect on OSR and EORT

\begin{tabular}{|c|c|c|c|c|c|c|c|c|c|}
\hline & \multicolumn{3}{|c|}{ OSR > EO_RT } & \multicolumn{3}{|c|}{ OSR + ESE > EO_RT } & \multicolumn{3}{|c|}{ OSR $>$ ESE } \\
\hline & B & $\mathrm{SE}$ & $\beta$ & B & SE & $\beta$ & $\mathrm{B}$ & SE & $\beta$ \\
\hline Intercept & $1.48^{\star * *}$ & 0.26 & & 0.11 & 0.66 & & $5.69^{* * *}$ & 0.19 & \\
\hline OsR & $0.69^{* * *}$ & 0.06 & 0.67 & $0.67^{* * *}$ & 0.06 & 0.65 & $0.09^{* *}$ & 0.04 & 0.09 \\
\hline ESE & & & & $0.25^{\star *}$ & 0.11 & 0.13 & & & \\
\hline$F$ & $19.61^{\star * *}$ & & & $18.40^{\star * *}$ & & & $2.00^{\star *}$ & & \\
\hline$R^{2}$ & 0.50 & & & 0.51 & & & 0.09 & & \\
\hline
\end{tabular}

NOTES Notes for parameters: $\mathrm{B}=$ unstandardized parameters, $\beta=$ standardized parameters, ${ }^{* *} p<0.01,{ }^{* *} p<0.05,{ }^{*} p<0.10$.

path $c^{\prime}$ (path $a \times$ path $b$ ) $=0.417$. H3a is therefore not supported since the addition of the new variable (ESE) does not change the significant path; this means that the effect is very small, hence not significant.

Table 5 , in terms of $\mathrm{H}_{3} \mathrm{~b}$, highlights that OSR significantly predicts EORT in path $c$, where $F(8,163)=19.61, p<0.01, R^{2}=0.50, \beta=0.69, p$ $<0.01$, and suggests that when OSR increases by 1 unit, EORT increase by 0.5 units. ESE significantly predicts EORT in path $b$, where $F(9,162)=$ 18.40, $p<0.01, R^{2}=0.51 ; \beta=0.24, p<0.05$. The Sobel Test revealed that path $a=0.09$, path $b=0.24$, path $c=0.69$ and path $c^{\prime}$ (path $a \times$ path $\left.b\right)=$ o.66. When the mediator (ESE) was added, the slopes for OSR changed significantly, since adding ESE as a mediator causes a small change to the $R$-square value changes, meaning ESE plays a small role in explaining the variability in EORT. Hypothesis $3 \mathrm{~b}$ is therefore supported, indicating the presence of partial mediation by ESE on the relationship between OSR and EORT. 
These empirical findings can be interpreted in relation to prior studies and theory which specify that an important set of entrepreneurial capabilities are higher levels of ESE, which enable individuals to recognise innovations and engage in risk taking (Chen, Greene, and Crick 1998). This relationship is reaffirmed with the positive findings obtained in the present study, insofar as higher levels of eo seem to involve a dynamic interplay between organizational antecedents, such as organisational structure and rewards and ESE. Such interactions between organizational structure and rewards, ESE, and EO highlight the usefulness of employing social cognitive theory (SCT) in terms of explaining interactions between behaviour, personal factors, and contextual influences (Bandura 1989). Research shows that an entrepreneur who is high in ESE is likely to 'exert more effort for a greater length of time, persist through setbacks, and develop better' (Chen, Greene, and Crick 1998). Such behaviour is important in the public sector, since in order to behave entrepreneurially employees often have to reveal higher levels of ESE (Kearney and Meynhardt 2016). Moreover, the mediating effect of ESE on the relationship between organizational antecedents, such as structure and rewards, and $\mathrm{EO}$ is increasingly recognised in healthcare organizations (Carlucci, Mura, and Schiuma 2019). Such findings highlight the relevance of entrepreneurship as an effective means for public bureaucracies, such as public hospitals, to convert themselves into adaptable, more proactive units that deliver improved services through innovative practices (Kearney, Hisrich, and Roche 2009). Healthcare and public hospitals take in an enlarged share of income in developed and emerging countries alike, and Eo has the ability to supply healthcare at a lower cost while advancing inclusivity and higher quality (Ruff et al. 2011). In many emerging economies, one of the principal objectives of any organization is heightened effectiveness and efficiency which can be attained by constantly innovating, and cultivating higher levels of eo (Anwar, Clauss, and Issah 2021; Urban and Nkhumishe 2019).

\section{Conclusion}

This article brings original understandings into the relationship between organizational antecedents and $\mathrm{E} O$, while clarifying the mediating effects of ESE on this relationship. The findings have provided an important empirical contribution to explaining organizational antecedents and $\mathrm{EO}$ and ESE, and highlighted their relevance to the public hospital sector in South Africa. 
In South Africa, where this study takes place, the constitution specifies the 'right to health care services for all persons living within the Republic' (Republic of South Africa 2015). However, entrenched inequalities and problems of service delivery, coupled with poor management in South Africa's national health system frustrate innovativeness at public hospitals (National Department of Health 2017; Ruff et al. 2011). As a result, and despite its potential, entrepreneurial behaviour remains understudied and is not implemented in many firms in emerging economies, often hindering future economic growth (Urban and Nkhumishe 2019).

Based on the study findings it is recommended that hospital managers not only undertake innovations but also find new ways to do more with fewer resources, in other words to be proactive by the nurturing of EO. Due to recent conditions of increased fiscal pressure as a direct result of the Covid-19 pandemic it is necessary for managers not only to be more resourceful and amplify efficiency in the providing of services, but also become entrepreneurial in terms of fostering EO (Urban 2021).

Additionally, research-based educational training is required in the public sector healthcare system to foster and develop ESE to improve innovation performance among all employees. Training of managers and employees should focus on developing higher levels of ESE through direct interventions as well as through vicarious learning in terms of the $\mathrm{SCT}$, while at the same time consider the prevailing organizational structure and reward systems in the workplace. Research on SCT confirms that self-efficacy can be developed through training and role displaying (Bandura 1989). This means that entrepreneurial behaviour in the form of EO is essential to overcoming public sector bureaucracies and rigid structures, and managers are advised to devise and implement structures and performance rewards that encourage entrepreneurial efforts by all staff members, who must be supported by a sense of ESE (Urban 2021).

Furthermore, not only is the Covid-19 pandemic centre stage as a global issue threatening the global economy, but digitization is changing the business model of many organizations across all sectors and industries (Niemand et al. 2020). Consequently, understanding the role of EO and ESE is fundamental, as both of these phenomena require flexibility in organizational behaviour in terms of enhancing resources, proficiencies and systems, predominantly in emerging economies where firms are often attentive to developing 'low cost type innovations' (Al-Omoush, Simón-Moya, and Sendra-García 2020).

While the article contains some limitations, these offer possible future 
research opportunities. The study being cross-sectional in design prevents drawing conclusions regarding the causal relationship between the study variables. Moreover, the study collected data on perceptions which may have been prejudiced by perceptual and motivational biases of the individual respondents. In addition, the study surveyed public hospitals in only the Gauteng province in South Africa, and hence the generalizability of findings is somewhat limited. Caution is required in generalising the findings to other contexts, as the study findings may not be appropriate for other economies with different environmental and institutional conditions (Urban and Nkhumishe 2019). Notwithstanding these limitations, the study results offer a valuable interpretation of how EO is affected by different organizational factors and ESE in the hospital public sector. In general, researchers would be well advised to conduct investigations to develop a greater appreciation of the complexities of fostering EO in public sector organizations in emerging economies by investigating specific country contingency variables such as institutional voids and scarce infrastructure and resources.

\section{References}

Al-Omoush, K. S., V. Simón-Moya, and J. Sendra-García. 2020. 'The Impact of Social Capital and Collaborative Knowledge Creation on EBusiness Proactiveness and Organizational Agility in Responding to the Covid-19 Crisis.' Journal of Innovation and Knowledge 5 (4): 27988.

Anwar, M., T. Clauss, and W. B. Issah. 2021. 'Entrepreneurial Orientation and New Venture Performance in Emerging Markets: The Mediating Role of Opportunity Recognition. Review of Managerial Science. https://doi.org/10.1007/s11846-021-00457-w.

Bandura, A. 1989. 'Regulation of Cognitive Processes through Perceived Self-Efficacy'. Developmental Psychology 25 (5): 729-35.

Baron, R. M., and D. A. Kenny. 1986. 'The Moderator-Mediator Variable Distinction in Social Psychological Research - Conceptual, Strategic, and Statistical Consideration. Journal of Personality and Social Psychology 51 (6): 1173-82.

Carlucci, D., M. Mura, and G. Schiuma. 2019. 'Fostering Employees' Innovative Work Behavior in Healthcare Organizations.' International Journal of Innovation Management 24 (2): 2050014.

Chen, C. C., P. G. Greene, and A. Crick. 1998. 'Does Entrepreneurial SelfEfficacy Distinguish Entrepreneurs from Managers?' Journal of Business Venturing 13 (4): 295-316. 
Chen, J. Y. J., and B. Urban. 2018. 'Behavioral and Environmental Influences on Entrepreneurial Orientation.' Journal of Economics and Behavioral Studies 10 (5): 73-88.

Cooper, D. R., and P. S. Schindler, eds. 2014. Business Research Methods. New York: McGraw Hill Education.

Covin, J. G., and G. T. Lumpkin. 2011. 'Entrepreneurial Orientation Theory and Research: Reflections On A Needed Construct.' Entrepreneurship Theory and Practice 35 (5): 855-72.

Covin, J. G., and D. Miller. 2014. 'International Entrepreneurial Orientation: Conceptual Considerations, Research Themes, Measurement Issues, and Future Research Directions.' Entrepreneurship Theory and Practice 38 (1): 11-44.

Demircioglu, M., and F. Chowdhury. 2020. 'Entrepreneurship in Public Organizations: The Role of Leadership Behaviour.' Small Business Economics 54 (1): 1-17.

Deslatte, A., and W. L. Swann. 2020. 'Elucidating the Linkages between Entrepreneurial Orientation and Local Government Sustainability Performance.' The American Review of Public Administration 50 (1): 92109.

Estrin, S., J. Korosteleva, and T. Mickiewicz. 2020. 'Schumpeterian Entry: Innovation, Exporting, and Growth Aspirations of Entrepreneurs.' Entrepreneurship Theory and Practice. https://doi.org/10.1177/ 1042258720909771

Gauteng Department of Health. 2017. Annual Report 2016/2017. Pretoria: Government Printers.

Hornsby, J. S., D. F. Kuratko, D. T. Holt, and W. J. Wales. 2013. 'Assessing a Measurement of Organizational Preparedness for Corporate Entrepreneurship. Journal of Product Innovation Management 30 (5): 93755.

Kearney, C., R. D. Hisrich, and F. Roche. 2009. 'Public and Private Sector Entrepreneurship: Similarities, Differences or a Combination?' Journal of Small Business and Enterprise Development 16 (1): 26-46.

Kearney, C., and T. Meynhardt. 2016. 'Directing Corporate Entrepreneurship Strategy in the Public Sector to Public Value: Antecedents, Components and Outcomes.' International Public Management Journal 19 (4): 543-72.

Klein, P. G., J. T. Mahoney, A. M. McGahan, and C. N. Pitelis. 2010. 'Toward a Theory of Public Entrepreneurship. European Management Review 7 (1): $1-15$.

Kloepfer, K., and C. J. Castrogiovanni. 2018. 'Entrepreneurship: Venture Creation Sub Processes, Subdomains, and Interfaces.' International Entrepreneurship and Management Journal 14 (5): 681-96. 
Kuratko, D. F., M. H. Morris, and J. C. Covin. 2011. Corporate Innovation and Entrepreneurship. 3rd ed. Cincinnati: South Western Publishing.

Kuratko, D. F., and M. H. Morris. 2018. 'Corporate Entrepreneurship: A Critical Challenge for Educators and Researchers.' Entrepreneurship Education and Pedagogy 1 (1): 42-6o.

Liu, Y., and M. Wang. 2020, 'Entrepreneurial Orientation, New Product Development and Firm Performance: The Moderating Role of Legitimacy in Chinese High-Tech smes.' European Journal of Innovation Management. http://doi.org/10.1108/EJIM-05-2020-0204.

Maresova, P., I. Soukal, R. Stemberkova, and K. Kuca. 2020. 'Innovation in the Public Sector in a Small Open Economy-Initial Investigation of Patent Activity at the Czech Universities.' Journal of Innovation and Entrepreneurship 9 (1): 1-16.

Meynhardt, T., and F. E. Diefenbach. 2012. 'What Drives Entrepreneurial Orientation in the Public Sector? Evidence from Germany's Federal Labor Agency.' Journal of Public Administration Research and Theory 22 (4): 761-92.

Morais, M., J. Valadares, M. Emmendoerfer, and T. Resende. 2020. 'What Evidence of Entrepreneurship in the Public Sector? An Analysis of International Scientific Production Abstract.' Management and Business Entrepreneurship 9 (9): 454-74.

Morris, M. H., and F. F. Jones. 1999. 'Entrepreneurship in Established Organizations: The Case of the Public Sector' Entrepreneurship Theory and Practice 24 (1): 71-91.

National Department of Health. 2017. White Paper on National Health Insurance: Towards Universal Health Coverage. Pretoria: Government Printers.

Newman, A., M. Obschonka, S. Schwarz, M. Cohen, and I. Nielsen. 2019. 'Entrepreneurial Self-Efficacy: A Systematic Review of the Literature on its Theoretical Foundations, Measurement, Antecedents, and Outcomes, and an Agenda for Future Research.' Journal of Vocational Behavior 110 (3): 403-19.

Niemand, T., C. Rigtering, J. P. Coen, A. Kallmünzer, S. Kraus, and A. Maalaoui. 2020. 'Digitalization in the financial industry: A Contingency Approach of Entrepreneurial Orientation and Strategic Vision on Digitalization.' European Management Journal. http://doi.org/10 $.1016 /$ j.emj.2020.04.008.

Özcan, S., and T. Reichstein. 2009. 'Transition to Entrepreneurship from the Public Sector: Predispositional and Contextual Effects.' Management Science 55 (4): 604-18.

Pérez-Luño, A., J. Wiklund, and R. V. Cabrera. 2011. 'The Dual Nature of Innovative Activity: How Entrepreneurial Orientation Influences In- 
novation Generation and Adoption.' Journal of Business Venturing 26 (4): 555-71.

Poon, J., R. A. Ainuddin, and S. H. Junit. 2006. 'Effects of Self-Concept Traits and Entrepreneurial Orientation on Firm Performance.' International Small Business Journal 24 (1): 61-82.

Republic of South Africa. 2015. Constitution of South Africa. Pretoria: Government Printer.

Ruff, B., M. Mzimba, S. Hendrie, and J. Broomberg. 2011. 'Reflections on Health-Care Reforms in South Africa.' Journal of Public Health Policy 32 (1): 184-92.

Schumpeter, J. A. 1934. 'The Theory of Economic Development.' Cambridge: Harvard University Press.

Statistics South Africa. 2018. Mid-Year Population Estimates Report 2018. Pretoria: Government Printers.

Strow, B., and C. Strow. 2018. 'Institutional Barriers to Productive PublicSector Entrepreneurship: An Exploratory Analysis.' Journal of Entrepreneurship and Public Policy 7 (4): 306-19.

Urban, B. 2021. 'Public Sector Entrepreneurial Orientation in South Africa: A Focus on Organisational Boundaries, Strategy and Resources.' International Journal of Entrepreneurship and Innovation Management 25 (1): 1-19.

Urban, B., and P. Maboko. 2020. 'Corporate Sustainability: A Focus on Entrepreneurship, Collaboration and Regulation in the South African Healthcare Industry' International Journal of Innovation and Sustainable Development 14 (2): 199-218

Urban, B., and M. Nkhumishe. 2019. 'Public Sector Entrepreneurship in South Africa.' Journal of Entrepreneurship and Public Policy 8 (4): 50012.

Wales, W. J., A. Corbett, L. Marino, and P. Kreiser. 2020. 'The Future of Entrepreneurial Orientation (EO) Research.' In Entrepreneurial Orientation: Epistemological, Theoretical, and Empirical Perspectives, edited by A. K. Corbett, P. Marino, and L. W. Wales. Bingley: Emerald.

Wales, W. J., S. Kraus, M. Filser, C. Stöckmann, and J. Covin. 2021. 'The Status Quo of Research on Entrepreneurial Orientation.' Journal of Business Research 128 (c): 564-77.

Wojcik-Karpacz, A., J. Karpacz, and J. Rudawska. 2019. 'Exploration and Exploitation of Good Practices by Technology Parks: Empirical Findings from Poland.' Managing Global Transitions 17 (4): 317-34.

Zuckerman, H. S., W. L. Dowling, and M. L. Richardson. 200o. 'The Managerial Role.' In Health Care Management: Organization Design and Behavior, edited by S. M. Shortell and A. D. Kaluzny, 34-60. 4th ed. Albany, NY: Delmar. 


\title{
Analysis of Selected Aspects of an Organisation: The Organisation as an Instrument, an Interest Group and as a Process
}

\author{
Dušan Gošnik \\ University of Primorska, Slovenia \\ dusan.gosnik@fm-kp.si \\ Klemen Kavčič \\ University of Primorska, Slovenia \\ klemen.kavcic@fm-kp.si
}

In this article, we discuss selected aspects of organisation: organisation as an instrument for achieving objectives, and organisation as an interest group, as well as defining the organisation as a process. Based on a literature review we have summarised the findings of different authors and presented what defines the organisation from the aforementioned aspects. The structure of the article follows the AIMRaD methodology: abstract, introduction, methodology, research and analysis, and discussion (Cargill and O'Connor 2009). The literature study research method was used. Findings are presented descriptively and in tabular form with a discussion and comments. Findings of this research are useful for the general, professional public, for the management of different organisations and for researchers from the fields of organisation and management, because selected aspects of organisations are intertwined, and their understanding is related to the basic management activities of each organisation such as planning, organising, leading and supervising and thus related decision-making.

Key Words: aspects of organisation, interest group, instrumental aspect, process aspect, analysis

JEL Classification: D21, D23, L22

(c) BY-SA https://doi.org/10.26493/1854-6935.19.167-181

\section{Introduction and Theoretical Background}

Organisations can be studied from different angles, e.g. sociological, technological, psychological, as a business or machine, an organism, a brain, as flows and change, a system, as an instrument, an interest group or a process.

If we are interested in people's behaviour, we can study the organisation from a sociological point of view $(\mathrm{Oh} 2 \mathrm{O} 20,558)$. The organisation as a social formation strives to achieve a common goal (Bavec and Manzin 2012, 
27). If we are interested in the technology used by an organisation, we will be interested in the technological aspect of the organisation. This can be interesting from many perspectives. For example, today we are dealing with increasing use of information technology and thus related issues in organisations are: how is new knowledge created, how is knowledge shared within organisations, how do sharing practices between organisations support innovations (Chatterjee, Ghosh, and Chaudhuri 2020, 1261; Hutahayan 2020, 1289; Khawaya et al. 2020, 237; Veiga et al. 2021, 590).

If we look at an organisation as an environment of pressures and hardships, victories and defeats, cooperation and trust, the social aspect of employment, and how employees experience it, we will be interested in the psychological aspect of the organisation (Bavec and Manzin 2012, 27; Valitova and Besson 2021, 3).

Understanding the organisation as an instrument (a machine) is similar to understanding the operation of a well-oiled machine to achieve a goal. The organisation can also be an instrument of power in this respect. In such a machine, people (employees) are like its wheels. This kind of understanding was typical at the beginning of the last century (Taylor 1911). Because tangible and intangible assets flow through organisations, and because organisations create value for customers in these flows, they can also be understood as flows and change (Suárez-Barraza, Miguel-Dávila, and Morales-Contreras 2021, 29).

An organisation as an organism is comprised of people that change, trigger changes in an environment, and also respond to changes from the environment. From this perspective, organisations are living organisms, just like the human body. An organisation as a system changes the input quantities (people, raw materials, technology, energy, and information) into outputs (products and services). In the same way, we can also understand and study organisations as a process in which we transform inputs into products/services (Tavčar 2008; 2009, 107; Škrinjar and Trkman 2013; Gošnik 2019a; 2019b).

Different authors worldwide (Kovačič and Bosilj-Vukšić 2005; Škrinjar and Trkman 2013; Trkman et al. 2015; Hernaus, Bosilj-Vukšić, and Indihar-Štemberger 2016; Latif et al. 2020; Kwayu, Abubakre, and Lal 2021; Lodgaard and Dransfeld 2020) have studied organisation as a process. In the literature there are missing studies about specific aspect of an organisation, such as the organisation as an instrument for achieving objectives, or the organisation as an interest group and thus related comparison studies, which has been detected as our research gap. 
The aim of this study is to emphasise importance of understanding organisations from different angles and to describe instrumental, interest aspect of organisations and process-oriented organisations.

In this article we have limited our study to selected aspects of an organisation such as: organisation as an instrument for achieving goals, an interest group and an organisation as a process. From research methodology aspect we have limited ourselves to the literature review approach.

This paper is organised as follows: (1) introduction, (2) research methodology, (3) research and analysis, (4) summary of the findings, with discussion and (5) conclusion with possible further research in this field.

\section{The Research Methodology}

Based on the study of domestic and world literature from the field of management and organisation, we researched selected aspects of organisations: organisations as an instrument, an interest group, and as a process. The systematic review was conducted within the following list of sources: Emerald, JS TOR, and Springer. Keywords such as: interest, instrumental, mechanic, organic, process, and aspect organisation were used. Based on the study of the literature in this field from 1990 onwards and citations of different authors, which includes also the latest sources from 2020 and 2021, we present and discuss findings as defined in the research questions. Comparison of the findings by different authors are presented and discussed. In this research we answered the following research questions (RQ):

$\mathrm{RQ} 1$ What defines an organisation as an instrument?

$\mathrm{RQ} 2$ What defines an organisation as an interest group?

$\mathrm{RQ} 3$ What defines an organisation as a process?

By synthesising the findings, we prepared summaries, brought them together in a tabular form, and provided comments. The findings are interesting for the general, professional public and the management of service and production organisations, as selected aspects of organisations are intertwined, and their understanding is related to the basic management activities of each organisation such as planning, organising, leading, and supervising as well as the related decision-making.

\section{Research and Analysis of Selected Aspects of Organisations}

According to the research questions, we present three selected aspects of the operation of each organisation in the following: (1) an organisation as 
TABLE 1 The Conception of Management Activities from an Interest and Instrumental Aspect

\begin{tabular}{lll}
\hline $\begin{array}{l}\text { The activity } \\
\text { of management }\end{array}$ & $\begin{array}{l}\text { The organisation as an in- } \\
\text { terest group }\end{array}$ & $\begin{array}{l}\text { The organisation as an in- } \\
\text { strument }\end{array}$ \\
\hline Planning & Conceptualizing ideas & Developing plans \\
Organizing & Connecting & Arranging, designing \\
Leading & Leading people & Managing business \\
Supervising & Assessing, judging & Measuring \\
\hline
\end{tabular}

NOTES Adapted from Tavčar $(2009,24)$.

an instrument, (2) an organisation as an interest group, and (3) an organisation as a process.

THE ORGANISATION AS AN INSTRUMENT FOR ACHIEVING GOALS

Every organisation can be observed as an instrument (machine, device) for achieving objectives, first and foremost subordinated to the interests of owners (Biloslavo 2006, 18; Tavčar 2008; 2009, 107; Gošnik 2019a; 2019b). This affects the company's core management activities, which are planning, organising, leading, and supervising (table 1).

Planning as part of management activities in instrumental terms is based on short-term results. It focuses primarily on fulfilling of the owner's interests. Managers put regulations on the front line and analytical decision-making prevails (Tavčar 2009, 107). In this case, planning focuses on existing services, existing products, maintaining current processes, high productivity, short term financial benefits and financial resources, and not on creating new core capabilities, new processes or new products and services (Tavčar 2009, 221-2).

Organising as a part of management activities in the instrumental aspect is called arranging (designing) and means primarily formalising, standardising work tasks, and sanctioning violators. Division of tasks among employees puts the needs of the organisation up front. Interests and wishes of employees are not so important. Process arranging (designing) is focused on determination of employee responsibilities. Achieving efficiency and high productivity of employees and processes predominate (Tavčar 2009, 328-9). Leading in the instrumental aspect focuses on business (documentation) and results. Financial decisions play a key role. Consequently, it also affects the core and supporting processes in an organisation, material flows, strategy, and quality. 
The leading style is autocratic, and management tries to circumvent co-workers' resistance. The focus is on existing products, not developing new ones. The organisation responds poorly to environmental influences (Tavčar 2009, 474-5). Supervising, as part of management activities in the instrumental aspect, is called measuring. Quantitative measurement of business performance is in the forefront. Employees are constantly supervised (controlled, monitored), the emphasis is on costs, economics, and the highest possible returns, is short-term oriented and oriented on quick wins (immediate results) (Tavčar 2009, 537).

Each organisation is not only an instrument for achieving goals but also an interest group (interest-based society) which we present below.

THE ORGANISATION AS AN INTEREST GROUP

The understanding of an organisation as an interest group is related to a social understanding of the purpose of organisations. Organisations perform better if they consider the interests of external participants (customers, suppliers and partners) and the interests of internal participants (employees, management and owners). The interest aspect emphasises the organisation as a society of interests of different participants (Biloslavo 2006, 18; Tavčar 2009, 107-8; Gošnik 2019a; 2019b).

Planning as a management activity within the aspect of interest can be called conceptualising ideas. Conceptualisation is subordinate to the interests of all participants (suppliers, employees, customers, managers, owners, and other market participants). It is oriented towards the longterm growth and performance of the organisation. Conceptualisation focuses on acquiring new knowledge and basic abilities, and in implementing goals and strategies, and emphasises coordination with as many participants as possible (Tavčar 2009, 222-3; Trkman et al. 2015, 250-66; Gošnik 2019a; 2019b).

Organising as a management activity within the aspect of interest is called connecting. Relationships between employees in the company are based, in this respect, on their interests and also on the interests of other participants (e.g. suppliers, customers), and create opportunities for creative cooperation between employees; cooperation between different participants is flexible (Tavčar 2009, 329-30). The interest aspect emphasises people (employees) and is therefore called leading people or co-workers (employees). It is characterised by dealing with employees and other participants of the organisation as a source of new knowledge and ideas for further growth (Nodeson et al. 2012, 466; Gošnik 2019a; 
2019b). Organisations that in-corporate external knowledge are more likely to achieve product innovations (Hernández, Nieto, and Rodríguez $2021,155)$. Knowledge generation and knowledge flow have a central role in achieving innovation and company performance and competitive advantage (Hutahayan 2020, 1289; Obeso et al. 2020, 1859; Ramayah et al. 2020, 1021).

Leading employees in the interest aspect takes into account employees' needs and is based on knowledge. It is less authoritarian. Cooperation between participants is oriented towards the common benefit and satisfaction of different interests. Management consider the abilities of employees and communication between different participants, based on trust (Tavčar 2009, 476-9). The interest aspect of supervising can be called assessing (judging). Goals are the result of the interests of different participants. Business goals are assessed based on relative comparisons and understanding, through participant satisfaction and longevity. It is less strict than measuring and includes the intuition of the decision maker (Tavčar 2009, 537; 539; Gošnik 2019a; 2019b).

\section{THE ORGANISATION AS A PROCESS}

We can also look at any organisation through the prism of interconnected processes, and not as a hierarchical organisational structure. Until recently, the prevailing opinion was that the most important thing for the successful operation of an organisation is to define the organisational structure. These days it is true that we put processes in the foreground and those organisational structures and rules, as elements pertaining to the orderliness of the organisation, follow processes (Bavec and Manzin $2012,13)$. Vila (2000, 81) says that if the processes in an organisation cease to function, the organisation also ceases to function, regardless of the fact that the structure still remains in place. This, therefore, requires organisations to focus on processes rather than structures. We are increasingly replacing the traditional view of the organisation as a hierarchy with a process view, which states that every organisation is a process (Markič 2003; Škrinjar and Trkman 2013, 48). An organisation as a process is like a system that responds to inputs and generates outputs. Processes in an organisation direct managers to consider who customers are, what they expect, what value they expect, what we can offer them, what else to improve, what processes would enable us to meet customer expectations and what resources we need to do so.

Processes also guide managers to consider new strategies and produc- 
tivity. More and more companies use process orientation also because functional organisation is an obstacle for organisations, as it prevents effective integration between individual functional areas (departments) and market responsiveness (Kovačič and Bosilj-Vukšić 2005, 32; Škrinjar and Trkman 2013, 48). Managing processes is today basic requirement for further development of companies, no matter their size and field of operation (Trkman et al. 2015; Hernaus, Bosilj- Vukšić, and IndiharŠtemberger 2016). From this perspective, managers should be primarily interested in the processes that take place in organisations (Gošnik 2019a; 2019b; Latif et al. 2020; Kwayu, Abubakre, and Lal 2021; Lodgaard and Dransfeld 2020). The process view of an organisation requires a flatter organisation and an integration of business functions in order to effectively develop new value for the market (Potočan and Nedelko 2015, 21). The processes within organisations also enable the more efficient servicing of customers, and improving existing and designing new processes; quality becomes a condition for successful business, it eliminates the problem of hierarchical business functions, and in the face of challenges sets the teamwork cooperation among employees (as well as suppliers and other market participants), just as business process implementation time is a key factor in competitiveness (environmental responsiveness, overtaking competitors) and similarly tailored strategies (Glavan-Milanović 2011, 25; Suárez-Barraza, Miguel-Dávila, and Morales-Contreras 2021, 29). According to Hrabal et al. (2020, 275) the human role presents the most important factor at в Р м implementation.

Kovačič et al. $(2004,61)$ states that organisations that make the transition to a process oriented organisation experience the following changes (table 2).

There are several reasons for the transition from a classical (functional) to a process organisation: (1) complicated transfer of information along the vertical hierarchy; (2) large delays during the transmission of information, documents, material, etc. between functions, departments or services; (3) the danger that functional departments do not cooperate enough (Unterlechner, Meško Štok, and Markič 2009, 118-9).

Looking at an organisation as a process is nothing new these days. Throughout history, humans have always dealt with processes. From the Industrial Revolution and the emergence of factories in the 18th century, the field of management also developed. Managers primarily focused on production processes. Among them was Henry Ford, who founded the Ford Motor Company in 1903 and designed a new concept for the pro- 
TABLE 2 Traditional and Process View of an Organisation

\begin{tabular}{|c|c|c|}
\hline Issue & $\begin{array}{l}\text { Traditional } \\
\text { organisation }\end{array}$ & $\begin{array}{l}\text { Process-oriented } \\
\text { organisation }\end{array}$ \\
\hline Emphasis in organisation & Business function & Business Process \\
\hline Organisational unit & Department & Working group/team \\
\hline Description of the work & Narrowly defined & Wide \\
\hline Focus & Supervisor & Customer/buyer \\
\hline The role of leadership & Supervision & Mentorship \\
\hline The key person & Business Director & $\begin{array}{l}\text { The owner (administrator) } \\
\text { of the process }\end{array}$ \\
\hline Business culture & Conflict-oriented & Cooperation \\
\hline
\end{tabular}

nOtes Adapted from Kovačič et al. (2004, 61).

duction of the car - the assembly line. Work was standardised, a limited number of versions were produced and of only one colour. Therefore, production costs were low and cars became more affordable. This also resulted in changes to other processes in the factory, to procurement, and suppliers (Unterlechner, Meško Štok, and Markič 2009, 120-6).

Mogensen and Rausa (1989) came to the realisation that the greatest loss in processes is the disregard for the professional and experiencebased abilities of workers to implement changes in processes. He emphasised the need to measure processes, be open to change, understand processes, and understand and emphasise human relationships; the ability to take an analytical approach to problem-solving; a cleaner and tidier work environment; and the ability to accept improvements (Mogensen and Rausa 1989; Unterlechner, Meško Štok, and Markič 2009, 120). The manufacturer market was slowly transitioning towards a customer market. The supply of products was becoming greater than demand. This resulted in the need for organisations to introduce new changes into their operations and thus into their processes (Unterlechner, Meško Štok, and Markič 2009, 25).

In 1990, Rummler and Brache found that most problems in processes arise when work passes from department to department. As a solution, they presented the idea of managing the process as a whole. The term Business Process Reengineering (B PR) was developed (Rummler and Brache 1990). According to Champy (1995), B PR organisations needed to treat business processes as comprehensive, ranging from order activity to product delivery, and use the necessary information technologies 
to help them interconnect. Many B P R attempts were unsuccessful. Managers had become more cautious. The advent of new data processing software made it easier to capture and process data and produce the reports needed to run businesses. That led to redundancies in management services. Under the pretext of в P R, organisations carried out a reduction in the number of employees, and so в PR gained a bad reputation and at the end of the gos fell into oblivion. As an alternative, many organisations began to use new terms to describe business process rearrangements, such as Business Process Improvements (B PI) or Business Process Redesign (Unterlechner, Meško Štok, and Markič 2009, 25).

A period of business standardisation followed. Approaches such as Total Quality Management (TQM) have emerged. According to Edward Deming, TQM envisages the continuous improvement of all organisational processes, products, and services and is based on the assumption that quality improvement is a key factor in achieving business efficiency and effectiveness (Kovačič et al. 2004, 68; Chatterjee, Ghosh, and Chaudhuri 2020, 1261). TQM strives to ensure that there are no errors in processes, to continuously improve processes, employee cooperation and development, and quality as dictated by the customer. Findings of Babu and Thomas $(2021,157)$ show positive direct and indirect effects of TQM on employee satisfaction as well.

These days, the competitiveness of any organisation stems from the competitiveness of core processes (Gošnik 2019a; 2019b). The common features of core processes are: (1) core processes must have a recognisable benefit for customers; (2) core processes must be difficult to copy; and (3) core processes must be irreplaceable with other solutions (Sinur, Odell and Fingar 2013 in Potočan and Nedelko 2015; Gošnik 2019a; 2019b). Support processes, on the other hand, enable organisations to harmonise core processes with standards, legal requirements, and business instructions (Potočan and Nedelko 2015, 46). Supporting processes include (Smith and Fingar 2003, 53): guarantee implementation processes, information support, invoicing, data management, order preparation, business performance monitoring, market analyses, and market analysis, etc.

\section{A Summary of the Findings and Discussion}

Different definitions of an organisation have many aspects in common. They define organisations as dynamic formations in which people (employees) play a key role; they are focused on achieving goals and benefitting society. We can study organisations from different perspectives, 
depending on the one we are interested in. We presented three selected aspects of the operation of organisations: the organisation as an instrument, the organisation as an interest group, and the organisation as a process. Every organisation is an instrument (machine, device) for achieving the goals of its owners. Understanding an organisation as an interest group is related to a broader social purpose of organisations. The interest aspect of an organisation emphasises the organisation as a community of interests of different participants. In every organisation, there is an instrumental (rigid, mechanical) and at the same time interest (soft, organic) aspect, regardless of the size, industry, or type of organisation. Long-term business success depends on the balance of these two aspects. This is reflected in all four basic management activities (planning, organising, leading and supervising). At the forefront of the notion of the functioning of organisations these days is the process aspect, with an emphasis on core processes. Core processes are comprehensive and dynamically coordinated sets of activities that enable the supply of customers (clients) with products and services. These take place in time and space, have clearly defined inputs and outputs (results), and must necessarily be coordinated. Consequently, in every company, it requires not only knowledge of the principles and mastery of general management, but above all the principles of business process management, with a focus on core business processes. Changes in business processes should be a constant practice and the work of managers in any company. When changing business processes, the connection of changes with the fundamental directions, goals, and strategies of each specific company must be taken into account. Successful management of an organisation as a process requires the involvement of customers, as products/services are intended for them, and processes must create value just for them. It should also involve employees as well as suppliers as they can be a source of ideas. Managing an organisation as a process with an emphasis on core processes is a particularly strategic opportunity for the development of new competitive advantages of organisations.

\section{Conclusion}

These days, there is a need for companies to simultaneously integrate different approaches into business process management, such as focusing on goals, customers, process control and quality; involving different participants; and standardising good practices, with the support of e.g., Six Sigma, Lean Management, and at the same time to manage basic sup- 
port processes, e.g. Lean Administration. Management in organisations must also integrate processes, strategy development, and goals in business process innovation in an appropriately comprehensive manner, with an emphasis on customer benefits (Lei, Leaungkhamma, and Le 2020, 481). According to Mooi, Rudd, and de Jong $(2020,741)$ process innovation is a key determinant of business performance (Mooi, Rudd, and de Jong 2020, 741). Innovation strategy has a significant effect on financial performance (Hutahayan 2020, 1289). Consequently, in every organisation, it requires not only knowledge of the principles and mastery of general management, interest, and instrumental, but above all the mastery of business processes with focus on core business processes (Gošnik 2019a; 2019b).

Every organisation can be observed as an instrument (machine, device) for achieving objectives and it is first subordinated to the interests of owners (Biloslavo 2006, 18; Tavčar 2008; 2009, 107; Gošnik 2019a; 2019b). This affects the company's core management activities, which are planning, organising, leading, and supervising.

Each organisation is also an interest group (interest based society). For better performance organisations should consider the following: organisations perform better if they consider interests of external participants (customers, suppliers and partners) and interests of internal participants (employees, management and owners) (Biloslavo 2006, 18; Tavčar 2009, 107-8; Gošnik 2019a; 2019b).

The interest aspect emphasises the organisation as a society of interests of different participants. Conceptualisation as an instrumental aspect of planning is subordinate to the interests of all participants (suppliers, employees, customers, managers, owners, and other market participants). It should be oriented towards the long-term growth and performance of the organisation. Relationships between employees in the company in the interest aspect should be based on their interests and also on the interests of other participants (e.g., suppliers, customers), and create opportunities for creative cooperation between employees (Tavčar 2009, 222-3; Trkman et al. 2015, 250-66; Gošnik 2019a; 2019b).

Leading employees in the interest aspect takes into account employees' needs and is based on knowledge. Knowledge generation and knowledge flow have a central role in achieving innovation and firm performance and competitive advantage. Business goals from the interest aspect should be based on relative comparisons and understanding, through participant satisfaction and longevity (Tavčar 2009, 537-9; Gošnik 2019a; 2019b).

Managing an organisation as a process is today a basic requirement 
for further development of companies, no matter their size and field of operation (Trkman et al. 2015; Hernaus, Bosilj-Vukšić, and IndiharŠtemberger 2016). From this perspective, managers should be primarily interested in the processes that take place in organisations (Gošnik 2019a; 2019b; Latif et al. 2020; Kwayu, Abubakre, and Lal 2020; Lodgaard and Dransfeld 2020).

This research is limited to defining an organisation as an interest group, an organisation as an instrument for achieving goals and an organisation as a process. From the research methodology aspect, this research is limited on the literature review approach.

Despite limitations, the findings of this research are useful for the general professional public, for the management of different organisations and for researchers in the field of organisation and management, as the selected aspects of organisations are intertwined, and their understanding is related to the basic management activities of each organisation: planning, organising, leading and supervising and thus related decisionmaking, regardless of size and industry of the organisation.

Further research in this area could be focused on the relation between different aspects of an organisation and company performance. Also, further research could be focused on systematic research of the literature in the field of other aspects of organisations, such as an organisation as a sociological formation, psychological formation, technological formation, organisation as flows, organisation as change, organisation as a system or organisation as a brain.

\section{References}

Babu, F., and S. Thomas. 2021. 'Quality Management Practices as a Driver of Employee Satisfaction: Exploring the Mediating Role of Organizational Image.' International Journal of Quality and Service Sciences 13 (1): $157-74$.

Bavec, C., and M. Manzin. 2012. Strukturni vidiki organiziranosti. Koper: Fakulteta za management.

Biloslavo, R. 2006. Strateški management in management spreminjanja. Koper: Fakulteta za management.

Cargill, M., and P. O'Connor. 2009. Writing Scientific Research Articles: Strategy and Steps. Chichester: Wiley-Blackwell.

Champy, J. 1995. Reengineering Management: The Mandate for New Leadership. London: Harper Collins.

Chatterjee, S., S. Ghosh, and Chandhuri, R. 2020. 'Knowledge Management in Improving Business Process: An Interpretative Framework for 
Successful Implementation of A I-CRM-KM System in Organizations.' Business Process Management Journal 26 (6): 1261-81.

Glavan-Milanovič, L. 2011. 'Understanding Process Performance Measurement Systems.' Business Systems Research 2 (2): 1-56.

Gošnik, D. 2019a. 'Core Business Process Management and Company Performance.' Management 14 (1): 59-86.

Gošnik, D. 2019b. Management temeljnih procesov: instrumentalni in interesni vpliv na uspešnost podjetij. Koper: Založba Univerze na Primorskem.

Hernández, V., M. J. Nieto, and A. Rodríguez. 2021. 'Product and Process Innovations and the Institutional Context of Transition Economies: The Effects of External Knowledge.' In The Multiple Dimensions of Institutional Complexity in International Business Research, edited by A. Verbeke, R. van Tulder, E. L. Rose, and Y. Wei, 155-70. Progress in International Business Research 15. Bingley: Emerald.

Hernaus, T., V. Bosilj-Vukšić, and M. Indihar-Štemberger. 2016. 'How to Go from Strategy to Results? Institutionalising в Р м Governance within Organisations.' Business Process Management Journal 22 (1): 173-95.

Hrabal, M., D. Tuček, V. Molnár, and G. Fedorko. 2020. 'Human Factor in Business Process Management: Modeling Competencies of в Р M Roles.' Business Process Management Journal 27 (1): 275-305.

Hutahayan, B. 2020. 'The Mediating Role of Human Capital and Management Accounting Information System in the Relationship between Innovation Strategy and Internal Process Performance and the Impact on Corporate Financial Performance.' Benchmarking: An International Journal 27 (4): 1289-318.

Latif, K. F., A. Nazeer, F. Shahzad, M. Ullah, M. Imranullah, and U. F. Sahibzada. 2020. 'Impact of Entrepreneurial Leadership on Project Success: Mediating Role of Knowledge Management Processes.' Leadership \& Organization Development Journal 41 (2): 237-56.

Kwayu, S., M. Abubakre, and B. Lal. 2021. 'The Influence of Informal Social Media Practices on Knowledge Sharing and Work Processes within Organizations.' International Journal of Information Management 58 (102280). https://doi.org/10.1016/j.ijinfomgt.2020.102280.

Kovačič, A., J. Jaklič, M. Indihar-Štemberger, and A. Groznik. 2004. Prenova in informatizacija poslovanja. Ljubljana: Ekonomska fakulteta.

Kovačič, A., and V. Bosilj-Vukšić. 2005. Management poslovnih procesov: prenova in informatizacija poslovanja s praktičnimi primeri. Ljubljana: GV založba.

Kralj, J. 2003. Management: temelji managementa, odločanje in ostale naloge managerjev. Koper: Fakulteta za management. 
Lei, H., L. Leaungkhamma, and P. B. Le. 2020. 'How Transformational Leadership Facilitates Innovation Capability: The Mediating Role of Employees' Psychological Capital.' Leadership \& Organization Development Journal 41 (4): 481-99.

Lodgaard, E., and S. Dransfeld. 2020. 'Organizational Aspects for Successful Integration of Human-Machine Interaction in the Industry 4.o era.' Procedia CIRP 88:218-22.

Markič, M. 2003. Inoviranje procesov kot pogoj za odličnost poslovanja. Kranj: Fakulteta za organizacijske vede.

Mogensen, A. H., and R. Z. Rausa. 1989. Mogy: An Autobiography; Father of Work Simplification. Chesapeake: Idea Associates.

Mooi, E., J. Rudd, and A. de Jong. 2020. 'Process Innovation and Performance: The Role of Divergence.' European Journal of Marketing 54 (4): 741-6o.

Nodeson, S., P. Beleya, G. Raman, and C. Ramendran. 2012. 'Leadership Role in Handling Employee's Resistance: Implementation of Innovation.' Interdisciplinary Journal of Contemporary Research in Business 4 (1): 466-77.

Obeso, M., R. Hernández-Linares, M. C. López-Fernández, and A. M. Serrano-Bedia. 2020. 'Knowledge Management Processes and Organizational Performance: The Mediating Role of Organizational Learning.' Journal of Knowledge Management 24 (8): 1859-80.

Oh, K. E. 2020. 'Social Aspects of Personal Information Organization.' Journal of Documentation 77 (2): 558-75.

Potočan, V., and Z. Nedelko. 2015. Poslovni procesi v organizacijah. Maribor: Self-published.

Ramayah, T., P. Soto-Acosta, K. K. Kheng, and I. Mahmud. 2020. 'Developing Process and Product Innovation through Internal and External Knowledge Sources in Manufacturing Malaysian Firms: The Role of Absorptive Capacity.' Business Process Management Journal 26 (5): 1021-39.

Rummler, G. A., and A. P. Brache. 1990. Improving Performance: How to Manage the White Space on the Organization Chart. San Francisco: Jossey-Bass.

Sinur, J., J. Odell, and P. Fingar. 2013. Business Process Management: The Next Wave. Tampa: Meghan-Kiffer Press.

Smith, H., and P. Fingar. 2003. Business Process Management. The Third Wawe. Tampa: Meghan-Kiffer Press.

Suárez-Barraza, M. F., J. A. Miguel-Dávila, and M. F. Morales-Contreras. 2021. 'Application of Kaizen-Kata Methodology to Improve Operational Problem Processes: A Case Study in a Service Organization.' International Journal of Quality and Service Sciences 13 (1): 29-44. 
Škrinjar, R., and P. Trkman. 2013. 'Increasing Process Orientation with Business Process Management: Critical Practices'. International Journal of Information Management 33 (1): 48-60.

Tavčar, M. I. 2008. Management in organizacija: celostno snovanje politike organizacije. Koper: Fakulteta za management.

Tavčar, M. I. 2009. Management in organizacija: sinteza konceptov organizacije kot instrumenta in kot skupnosti interesov. Koper: Fakulteta za management.

Taylor, F. W. 1911. The Principles of Scientific Management. New York: Harper.

Trkman, P., W. Mertens, S. Viaene, and P. Gemmel. 2015. 'From Business Process Management to Customer Process Management.' Business Process Management Journal 21 (2): 250-66.

Unterlechner, M., Z. Meško Štok, and M. Markič. 2009. Inoviranje, kakovost in Lean Six Sigma v proizvodnem procesu. Koper: Fakulteta za management.

Valitova, A., and D. Besson. 2021. 'Interpersonal Communications at Core of Conflicts' Escalation in Organization: The Interplay of Interpersonal Communication Escalation, People's Habitus and Psycho-Sociological Processes Are More Important Than Contextual Factors.' Journal of Organizational Change Management 34 (1): 3-27.

Veiga, P. M., P., R. Figueiredo, J. J. M. Ferreira, and F. Ambrósio. 2021. 'The Spinner Innovation Model: Understanding the Knowledge Creation, Knowledge Transfer and Innovation Process in smes.'Business Process Management Journal 27 (2): 590-14.

Vila, A. 200o. Organizacija v postmoderni družbi. Kranj:Založba Moderna organizacija. 